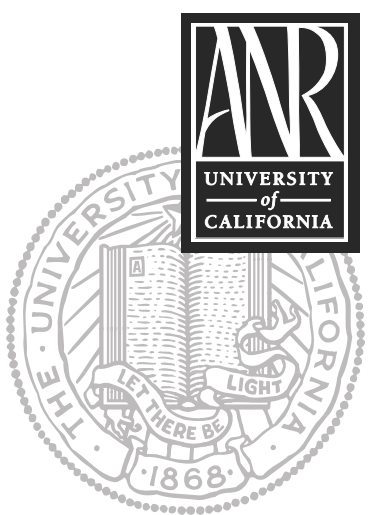

UNIVERSITY OF CALIFORNIA

Division of Agriculture and Natural Resources http://anrcatalog.ucdavis.edu

\title{
Rural Roads: A Construction and Maintenance Guide for California Landowners
}

SUSAN D. KOCHER, UC Cooperative Extension Natural Resources Advisor, El Dorado County; JARED M. GERSTEIN, Staff Research Associate, Center for Forestry, University of California, Berkeley; and RICHARD R. HARRIS, UC Cooperative Extension Specialist, University of California, Berkeley

Many thousands of miles of privately maintained rural roads extend throughout California, and they are used for resource management as well as residential and recreational access by over 500,000 landowners (fig. 1). The California Department of Forestry and Fire Protection (CAL FIRE) estimates that another 2.7 million acres of forest and rangeland will be developed over the next 40 years, requiring the construction of thousands of miles of new roads (CAL FIRE 2003). Poorly located, designed, or maintained roads are the primary cause of water quality degradation in rural watersheds.

This publication is designed to help rural landowners understand how to improve and maintain existing roads. It also provides guidance on planning new roads. It is written for people who have little to no previous experience in managing a road. If you have recently purchased a rural parcel or have become responsible for road maintenance on an existing parcel—or otherwise feel unprepared for maintaining roads-this publication should help you. It mainly addresses single-lane dirt or rocksurfaced rural roads, also known as "low-volume" roads because they are not expected to carry high traffic levels.

This publication should enable you to

- understand the basic principles of good road design and maintenance

- recognize current and potential road erosion and drainage problems

- consider remedial treatments that may be needed

- develop rough estimates for the costs of road improvements and maintenance

- communicate clearly with contractors who may perform work on your roads

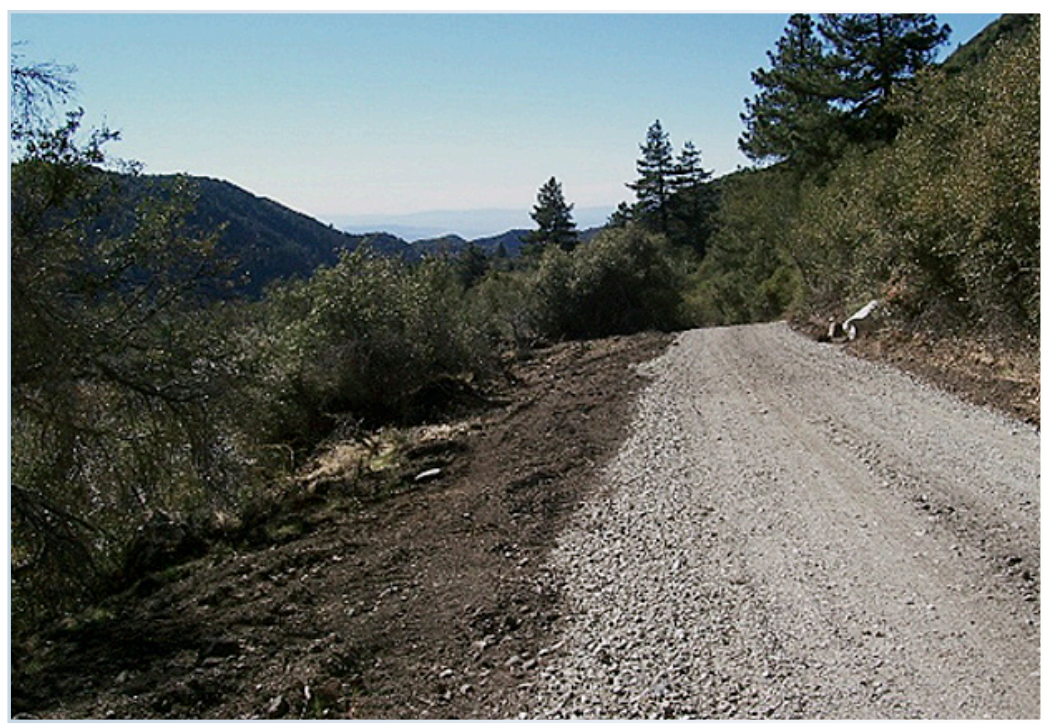

Figure 1. Low-volume road that has been newly graveled and out-sloped, San Bernardino County. Photo: Richard Harris. 


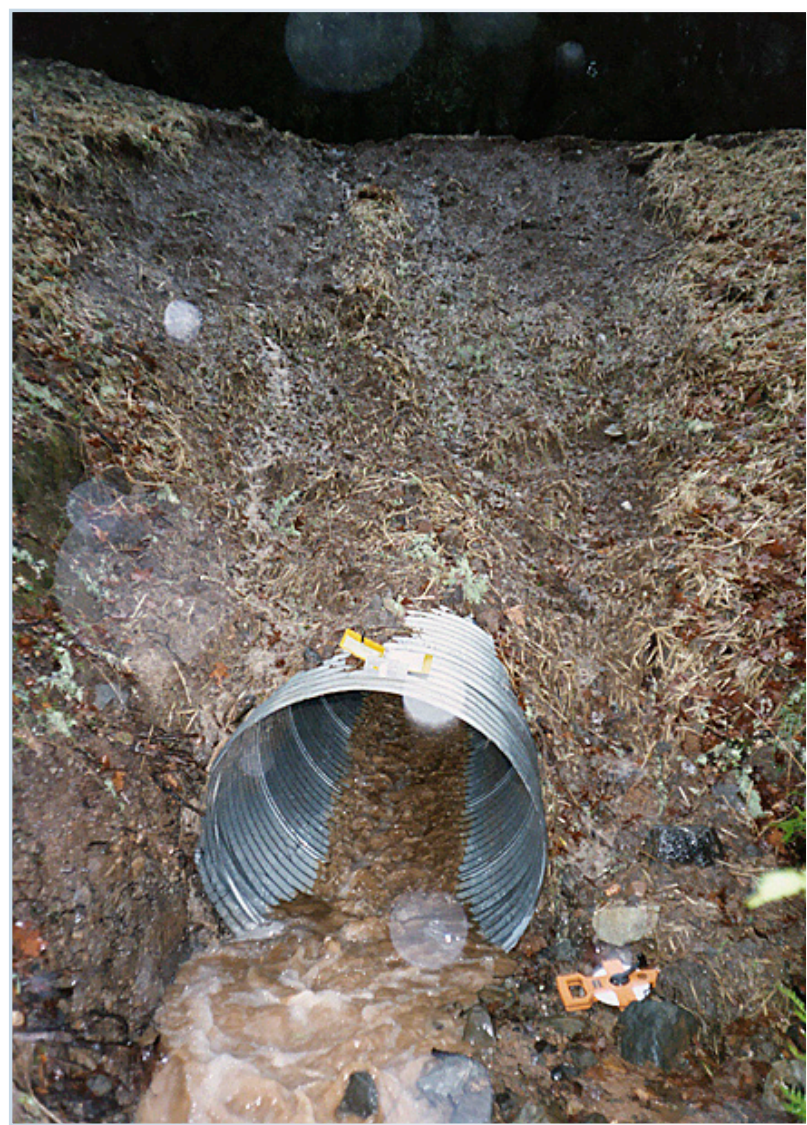

Figure 2. This cross drain delivers sediment from the roadside ditch under the road surface to a nearby stream. The road fill is also eroding. Photo: Jared Gerstein.

\section{WHY WORRY ABOUT ROAD DESIGN AND MAINTENANCE?}

Road maintenance should be considered an unavoidable necessity of living in a rural area. Landowners should take the time to learn about roads because when they are well designed and maintained they have fewer impacts on the environment, are more reliable, and cost less to maintain than problem roads.

\section{Environmental impacts}

Rural roads are a major source of sediment that ends up in stream channels (fig. 2). This is especially true for unpaved roads located near streams that are used year-round. Sediment delivered to streams from roads causes streams to run muddy and take a long time to clear after storms. Sediment can end up depositing in pools and adversely affect habitat for fish and other aquatic organisms.

\section{Reliability}

Poorly designed, located, or maintained roads have a higher risk of failing during storms than roads that are well constructed and maintained. Adequately sized culverts, free-flowing ditches, and properly drained road surfaces are essential elements of a reliable road network. Without these elements in place, even a moderate winter storm can render a road impassable.

\section{Cost of repetitive maintenance}

The bottom line is that it can be extremely expensive to maintain roads that are designed, located, or constructed poorly. It is usually more cost effective to identify and remedy chronic road problems than to treat only the symptoms of the problem year after year. For example, it will cost less in the long run to install proper drainage structures and rock surfacing on a road that gets muddy and rutted every winter than to regrade the road surface every spring.

\section{UNDERSTANDING ROAD COMPONENTS}

Although roads vary in their configuration and design, they have common elements that affect their functionality and durability. Roads must create a flat surface for vehicle travel on sloped land. To do this, part of the hillslope is cut away (the cut slope) and the removed soils are placed below (the fill slope) and compacted to create a flat bench or traveled way. This is called cut-and-fill construction (fig. 3). A balanced cut-and-fill project uses all the cut material to generate the fill. In full-bench construction, the cut is made wide enough to accommodate the entire traveled way (fig. 4). The cut mate-

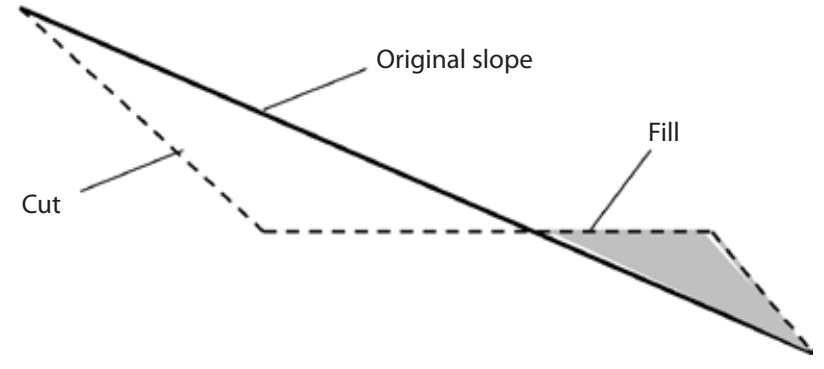

Figure 3. Cut-and-fill road construction design. Source: Kramer 2001.

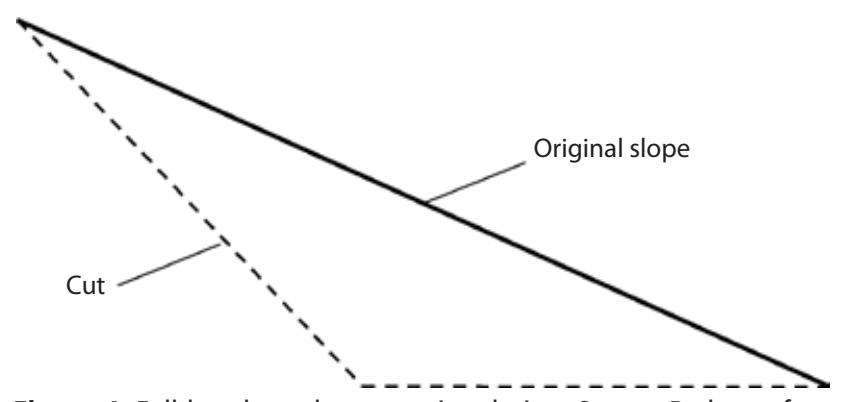

Figure 4. Full-bench road construction design. Source: Redrawn from Kramer 2001. 


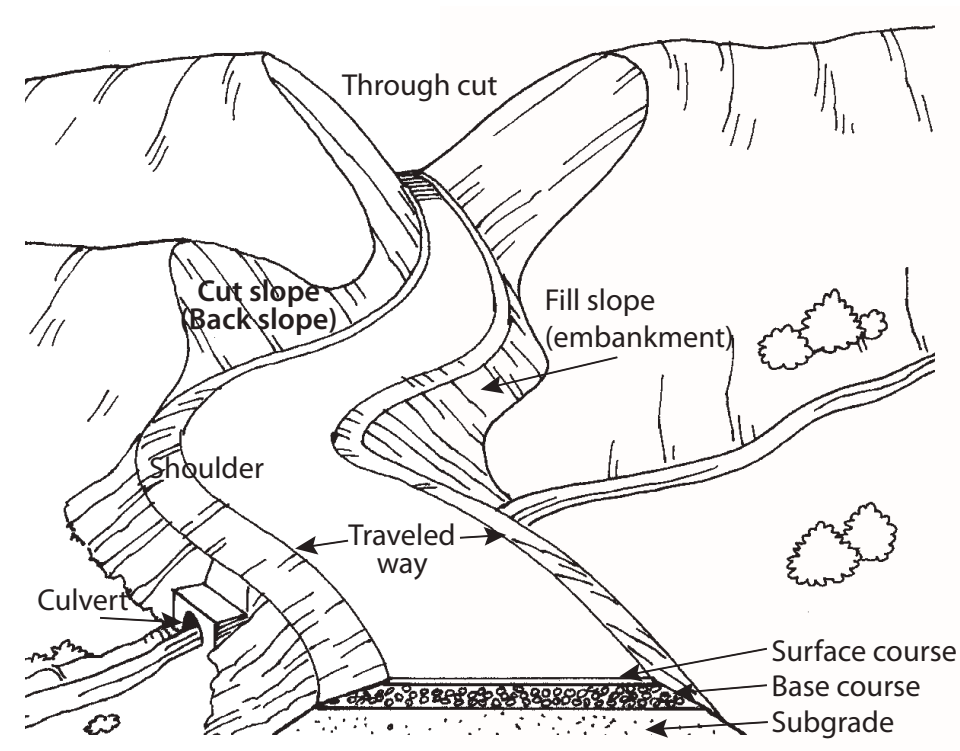

Figure 5. Components of a road. Source: Keller and Sherar 2003.

rial is not used in the road construction and must be hauled (end-hauled) to an off-site disposal area. Full-bench construction reduces the risk of fill slope failure but is usually more expensive due to hauling costs.

Ideally, a road should consist of three layers (fig. 5). The subgrade is the bottommost layer at the level of the in-place material. The base course is the main load-spreading layer and typically consists of gravels or gravelly soils, with sand and/or clay intermixed. The surface course or surfacing may consist of native materials, imported rock, or asphalt. It is placed on top of the base course to improve rider comfort, provide structural support, and weatherproof the road for wet season use. As a practical matter, many rural roads are not constructed in this way but consist entirely of native materials encountered during grading. This can be a factor contributing to poor performance.

All roads must incorporate features to drain water off the road surface and allow it to cross from one side to the other. Road drainage is the key to a road's integrity. Culverts are metal, concrete, or plastic pipes set beneath the road surface to drain ditches, springs, or streams crossed by the road. Culverts move water from the inside of the road (next to the cut slope) through a pipe to the outside of the road (to the fill slope or edge of bench). Ditches are used to collect water that accumulates from the road surface or hillslope on the inside or cut-slope side of an in-sloped road. Ditch relief culverts drain the accumulated water from the inside ditch to the outside of the road.

Besides culverts, common stream-crossing structures include bridges and lowwater crossings or fords. Bridges usually cause fewer environmental impacts than culverts because they may not alter the natural channel form or require placement of fill in the channel. However, they are often more expensive to install than culverts. Lowwater fords involve modifying and sometimes hardening a swale or stream channel to allow vehicles to drive through during low-flow periods (figs. 6 and 7). Less fill is introduced to the stream channel; however, vehicles driving through may input sediment to the stream continuously. Fords are typically impassable during high flows and so are rarely suitable for permanent roads.

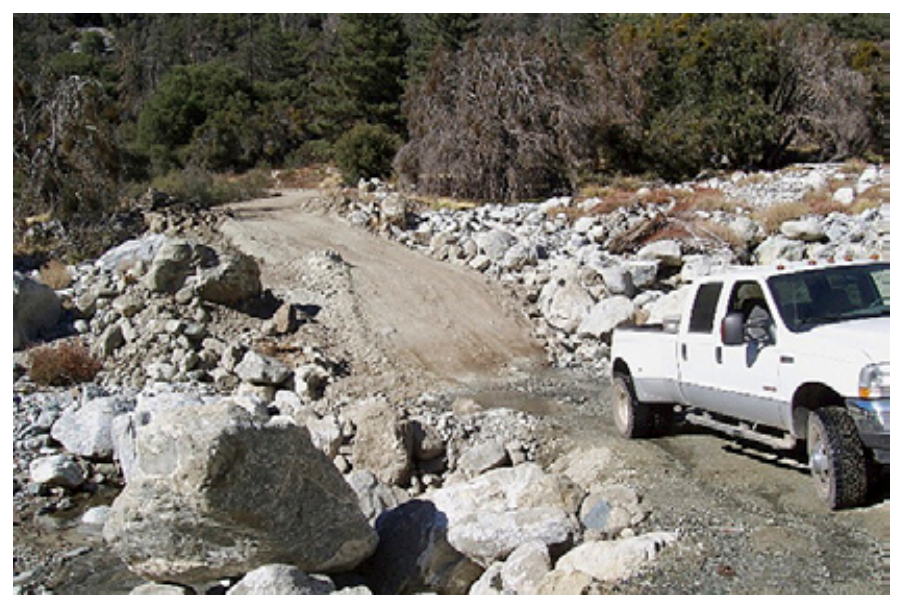

Figure 6. Low-water crossing on a perennial stream, San Bernardino County. Photo: Richard Harris.

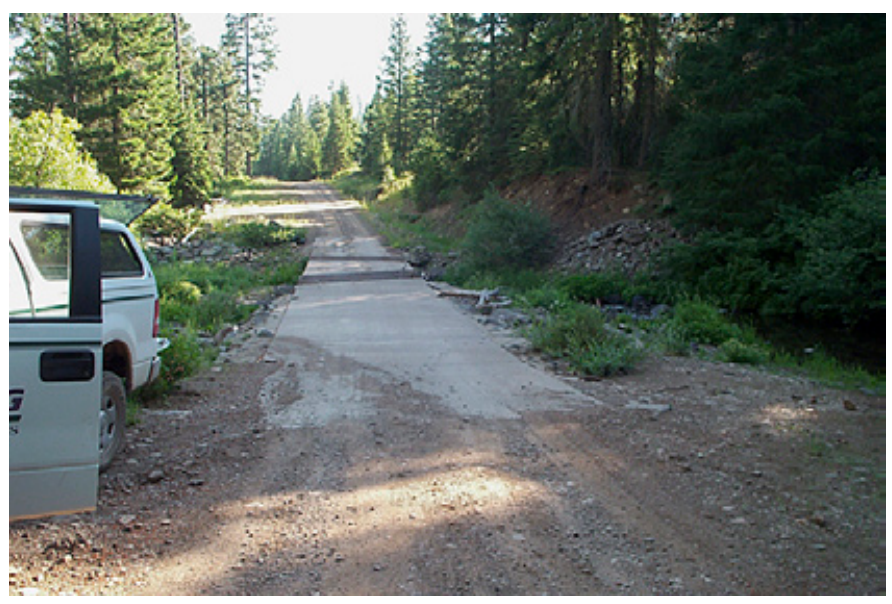

Figure 7. Concreted low-water crossing placed on bedrock outcrop in intermittent stream. Photo: Angela Wilson, Central Valley Regional Water Quality Control Board. 


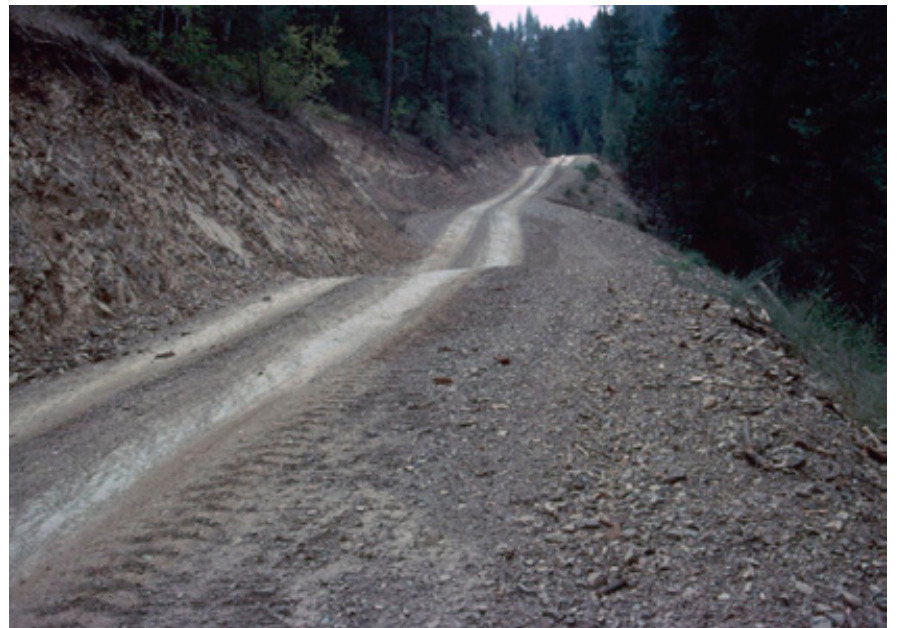

Figure 8. Rolling dips installed to drain an out-sloped road. Source: Bill Weaver, Pacific Watershed Associates.

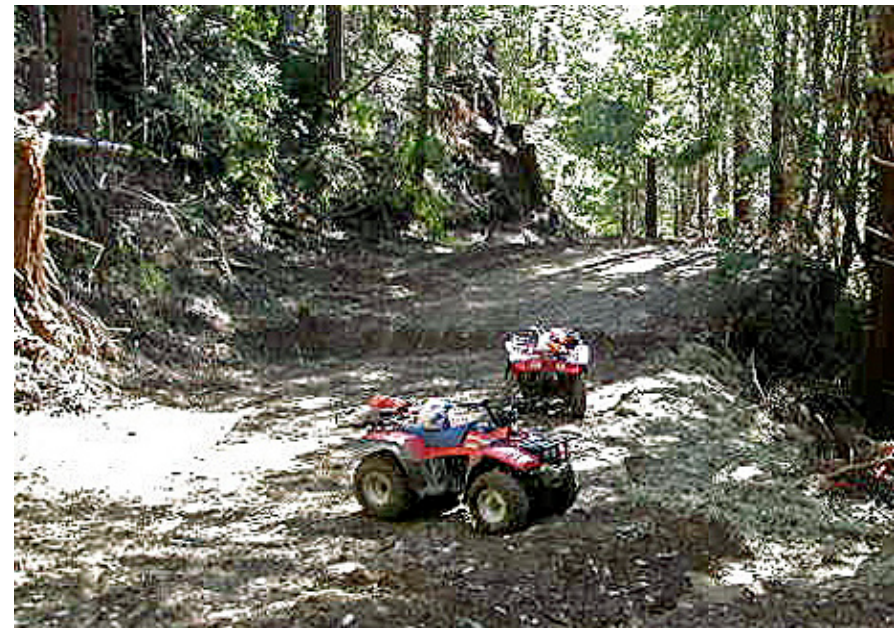

Figure 9. Water bars installed on a road after timber harvesting. Source: Angela Wilson, Central Valley Regional Water Quality Control Board.

Rolling dips are constructed breaks in the road grade designed to drain water directly from the road surface to the outside of a road without using an inside ditch or ditch relief culvert (fig. 8). They require vehicles to slow their speed of travel.

A water bar is a mound of soil and an accompanying ditch on the road surface that interrupts water flow and diverts it off the road surface (fig. 9). It is typically not passable by vehicles and so is not used on permanent roads. A berm is a ridge of rock, soil, or asphalt usually found on the outside of a road shoulder to control surface water. It directs runoff to specific locations where water can be discharged without causing erosion. Armoring is the placement of a layer of rock on cut or fill slopes or ditches to prevent water from eroding the soil.

\section{UNDERSTANDING ROAD DESIGN AND DRAINAGE}

Draining water from the road surface quickly, without letting it concentrate, is key to preventing erosion and thus to maintaining a stable driving surface. Two characteristics influence how well water drains from the road surface: the steepness of the road (i.e. its grade or gradient), and the shape and cross slope of the traveled way. The gradient of the road is determined by its location and routing; thus, it cannot be changed without moving the road. The cross-sectional shape and slope of a road are the pri-

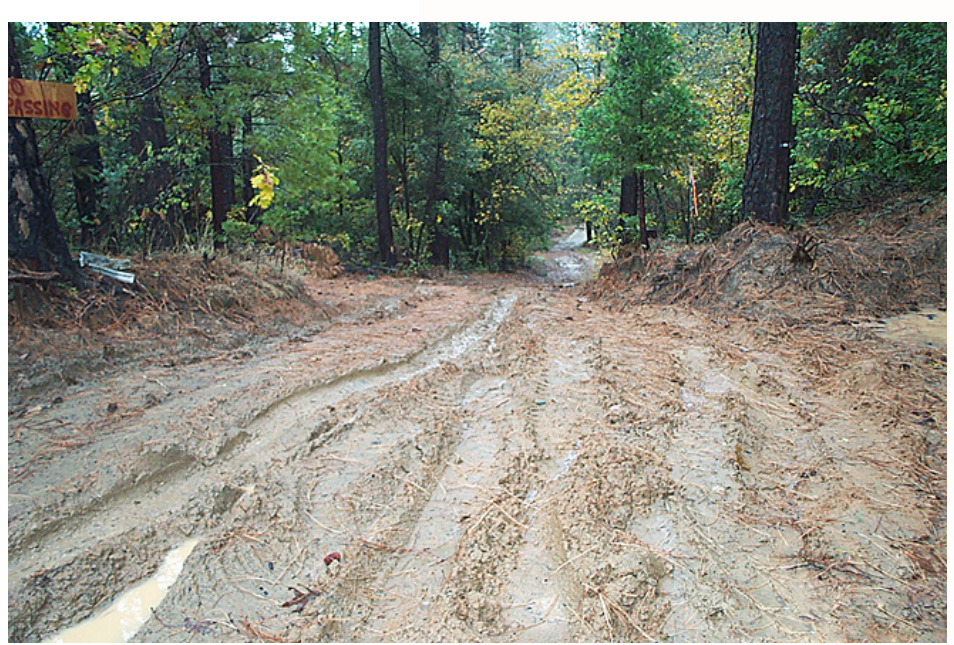

Figure 10. These ruts were created by wet-weather use of an unsurfaced, poorly drained road. Photo: Angela Wilson, Central Valley Regional Water Quality Control Board. mary design features that may be manipulated to improve drainage.

\section{Gradient}

Roads with a gentle gradient are easiest to maintain as long as the slope is adequate to drain the water off the road surface. In general, road grades need to be a minimum of two percent to facilitate drainage, so that water will not accumulate on the surface and saturate the subgrade. Saturated subgrades in combination with repetitive splash erosion due to vehicle traffic are responsible for potholes and ruts (fig. 10). Steeper roads drain water more quickly, but this allows the water to develop more erosive power, necessitating measures to prevent erosion and destabilization. 


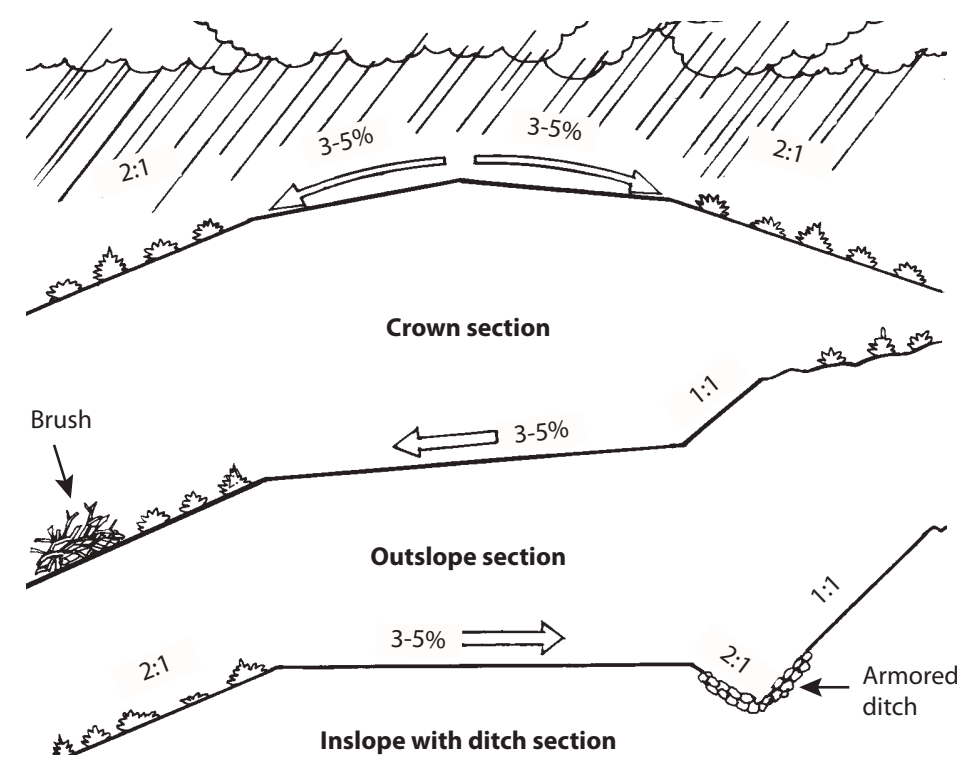

Figure 11. Typical road drainage options. Source: Keller and Sherar 2003.

\section{Shape and slope of the surface}

The shape and slope of the road surface determines how water will drain from it (fig. 11). In-sloped, out-sloped, and crowned roads drain water differently. The surface of an in-sloped road has a gentle tilt towards the cut slope of the hillside. Water collecting on the surface is drained into a ditch constructed between the road surface and the cut slope. Until recently, most roads in California were designed and constructed as in-sloped roads. When constructed in native materials, in-sloped roads are prone to erosion. Erosion can occur in the ditch, due to concentrated flow; on the road surface when ditch capacity is exceeded; or at the outfalls of culverts and cross drains receiving ditch flow. Ditch relief culverts must be installed frequently to accept ditch flow and dispose of it in a nonerosive manner.

Out-sloped roads are built with a slight angle of the road surface towards the fill slope. This allows the road surface runoff to sheet flow in a dispersed manner over the fill slope onto the adjacent hillside. Continuously concentrated runoff is avoided. Assuming that the fill slope and hillside are adequately vegetated or otherwise protected, no erosion occurs. Without a ditch, no ditch relief culverts are needed. This minimizes costs, reduces the chance of road failure due to culvert plugging, and may require less road width. Fill slopes may be armored to avoid erosion. Out-sloped roads may be difficult to drain on steep hillslopes and on road grades over 10 to 12 percent. They may be unsafe in areas with slippery soils or snow cover or in places where roads become icy, especially on curves where momentum would carry vehicles to the edge.

Crowned roads disperse water to each side of the road. They often require a system of ditches and cross drains which can be difficult to create and maintain. Therefore, they work best on two-lane roads with gentle grades or on the crest of hills.

\section{UNDERSTANDING THE TYPE OF ROAD NEEDED}

Deciding what kinds of roads you need for access to and on your property is an important step towards good stewardship. This includes considering whether or not existing roads are adequately designed for the intended uses. In some cases, existing roads may need to be upgraded to accommodate your uses or entirely new roads may be required.

The appropriate road design depends on the intended use. Roads with relatively high traffic levels, heavy truck use, or all-season use require a higher design standard and possibly a higher level of maintenance. In any case, the guiding principles should be to minimize erosion and ensure that the road is designed and maintained according to its use.

\section{All-season roads}

These are used year-round and are intended to be in continuous service for the foreseeable future. In rural subdivisions, these tend to be the "community roads" that run across multiple parcels and collect traffic from individual driveways. On timberlands or ranches, these permanent roads are the "haul roads" that can be used year-round, but receive most traffic during the dry season. Typically, all-season roads have rock 


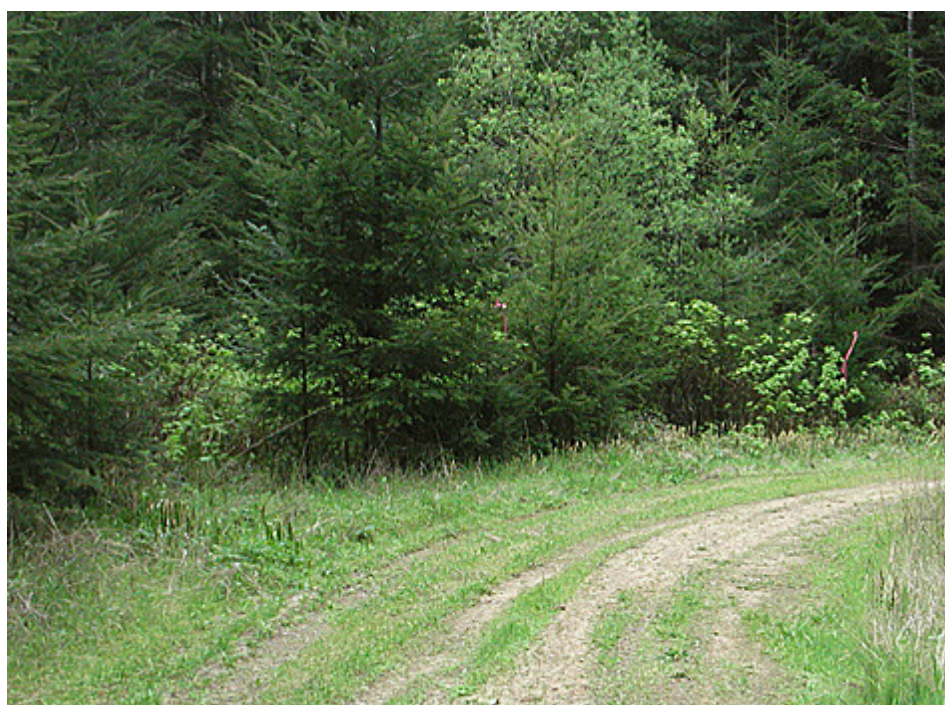

Figure 12. Grass cover on the surface of a road used for dry-season access. Source: Julie Bawcom, California Geological Survey. or other surfacing (at least on steep hills and near stream channels) and bridges or culverts at stream crossings. They may be in-sloped, out-sloped, or crowned alone or in combination. They may be graded and resurfaced regularly to maintain a smooth running surface.

\section{Seasonal roads}

These may be constructed to a lower standard because they are used only during the dry season (fig. 12). They are often permanent roads so they require provisions for drainage even if they are not used in the winter. Rock surfacing may not be required. Fords, rather than culverts or bridges, may be used at stream crossings, particularly if the streams do not flow in the summer. Seasonal roads may have a steeper gradient than all-season roads and utilize an out-sloping drainage design.

They may be closed after seasonal use and winterized by installation of water bars and revegetation of the road surface.

\section{Temporary roads}

These are used for only a short time and for a dedicated purpose, such as a timber harvest. Use is generally confined to the dry season and design standards may be minimal. Construction should minimize the volume of material excavated by following existing contours and cutting as little as possible. The road is closed after use, although the road bed may be retained for future use. Adequate closure should include removal of stream-crossing structures and associated fills along with installation of water bars to prevent any accumulation of water on the road surface. If vegetation cannot grow back on the road surface, it may be necessary to break up compaction and loosen the soil by 'ripping' it with a bulldozer. When closed, the entrance to the road should be blocked off to prevent all vehicle access.

\section{ROAD DESIGN PRINCIPLES}

\section{Construction}

- Minimize the number and length of roads in the watershed.

- Minimize the width of the road and the area disturbed during construction.

- Minimize road gradient. Gradient should be 12 percent or less.

- Use balanced cut-and-fill construction in gentle terrain.

- Avoid construction on steep slopes over 60 percent. Use full-bench construction where slopes over 60 percent cannot be avoided.

- Minimize cuts, fills, and vegetation clearing. Construct cut slopes on a 3/4:1 or flatter slope.

- Build fill slopes on a 1/1/2:1 or flatter slope.

\section{Streams}

- Stay as far away from streams as possible and minimize the number of crossings.

- Design crossings with adequate capacity to pass the 100-year storm flow plus the debris and sediment carried through the culvert during the storm. 


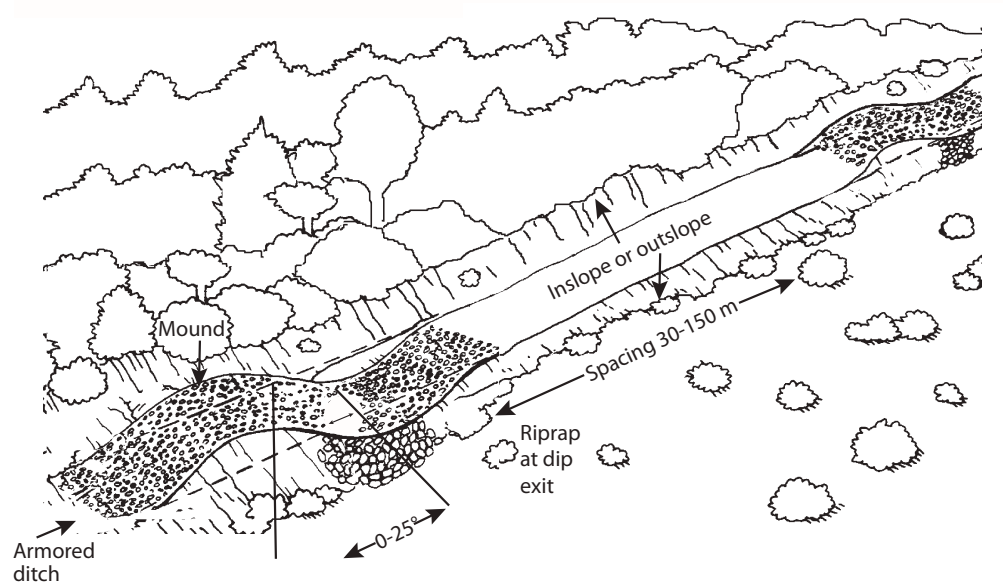

Figure 13A. Rolling dip on an out-sloped road. Proportions are exaggerated for clarity. (In practice, rolling dips can be subtle and still be effective.) Source: Keller and Sherar 2003.

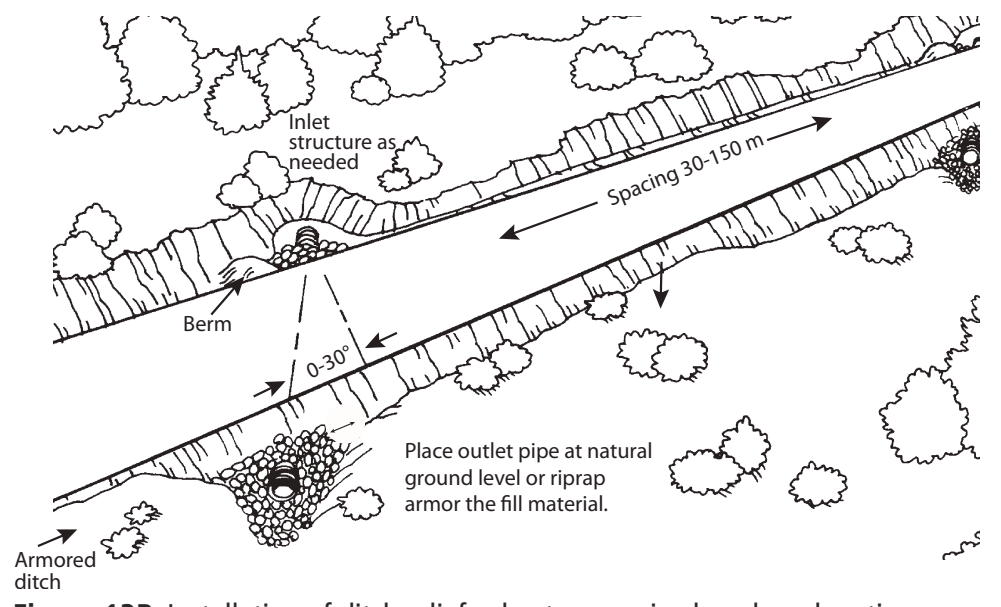

Figure 13B. Installation of ditch relief culverts on an in-sloped road section. Source: Keller and Sherar 2003.

Table 1. Rolling dip and ditch relief culvert recommendations

\begin{tabular}{|c|c|c|}
\hline $\begin{array}{c}\text { Road grade } \\
(\%)\end{array}$ & \multicolumn{2}{|c|}{ Soil erodibility } \\
\hline & $\begin{array}{c}\text { Low to non-ero- } \\
\text { sive soils (ft) }\end{array}$ & $\begin{array}{c}\text { Erosive soils } \\
\text { (ft) }\end{array}$ \\
\hline $0-3$ & 400 & 250 \\
\hline $4-6$ & 300 & 160 \\
\hline $7-9$ & 250 & 130 \\
\hline $10-12$ & 200 & 115 \\
\hline $12+$ & 160 & 100 \\
\hline
\end{tabular}

Source: Adapted from Keller and Sherar 2003.

Table 2. Water bar spacing recommendations

\begin{tabular}{|c|c|c|}
\hline $\begin{array}{c}\text { Road or trail } \\
\text { grade } \\
(\%)\end{array}$ & $\begin{array}{c}\text { Sow to non-erosive } \\
\text { soils } \\
\text { (ft) }\end{array}$ & $\begin{array}{c}\text { Erosive soils } \\
\text { (ft) }\end{array}$ \\
\hline $0-5$ & 250 & \\
\hline $6-10$ & 200 & 130 \\
\hline $11-15$ & 150 & 100 \\
\hline $16-20$ & 115 & 65 \\
\hline $21-30$ & 100 & 50 \\
\hline $30+$ & 50 & 40 \\
\hline
\end{tabular}

Source: Adapted from Keller and Sherar 2003.
- $\quad$ Reduce the potential for streams to be diverted onto the road surface by installing dips and trash barriers on streams that are not fish bearing.

- Protect crossing outlets with erosion control measures or downspouts.

- Facilitate fish passage, preferably by installing bridges, on fish-bearing streams.

- Use special techniques to cross meadows and other wet areas.

\section{Drainage}

- Provide adequate road surface drainage and minimize the concentration of runoff.

- Out-slope roads whenever practical. Road surfaces should slope 3 to 5 percent for road grades less than 10 percent. Install rolling dips for drainage (fig. 13A).

- In-slope road surfaces at an angle of 3 to 5 percent. Install ditch relief culverts (fig. 13B).

- Crown road sections with gentle slopes to prevent standing water on the road.

- Avoid wet and unstable areas.

\section{LOW-VOLUME ROAD DRAINAGE PRINCIPLES}

Situating and designing roads correctly from the outset will save a landowner years of worry and maintenance costs caused by avoidable road problems. The key to proper road design is to abide by established guidelines and hire good help. These guidelines can also be used to address maintenance problems on existing roads.

It is often said that the three most important considerations for road design are drainage, drainage, drainage! Drainage features should include ditch relief culverts for insloped roads and rolling dips for out-sloped roads. Rolling dips or ditch relief culverts of at least 12 inches in diameter should be spaced as necessary to effectively drain the road, and no further apart than every 400 feet (table 1). Adequate drainage control during the winter is also critical for seasonal and temporary roads. Water bars should be installed every 250 feet or closer when the road is closed (table 2). Drainage features should be spaced more closely on roads with steep grades or erodible soils composed of silt or fine sands. (A conversion table is provided at the end of this publication for calculating equivalents between English and metric systems of measurement.) 


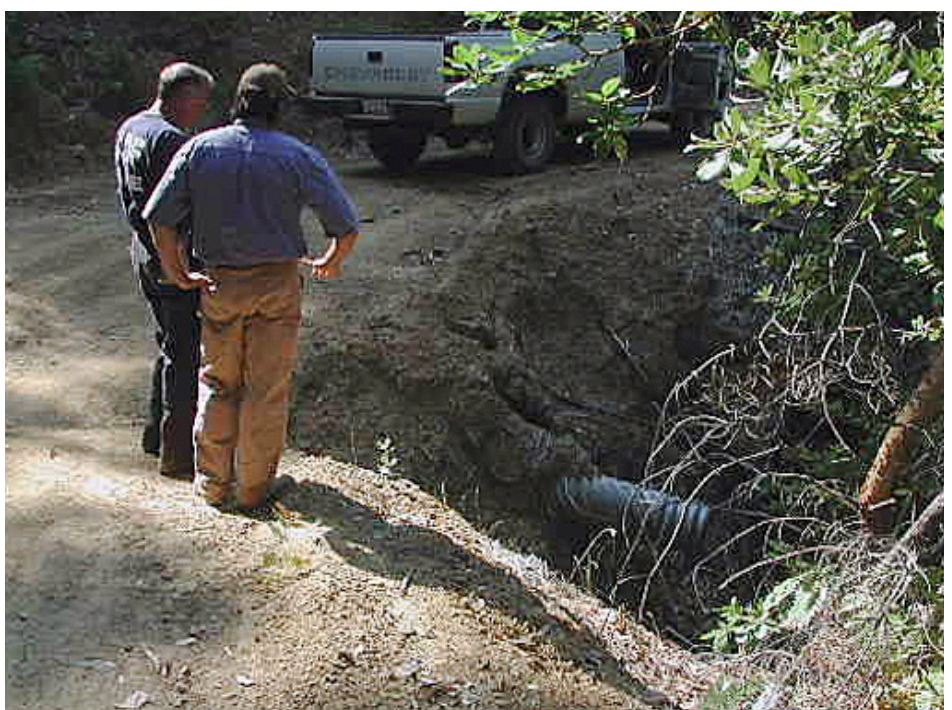

Figure 14. This fill slope erosion was caused by a plugged cross-drain inlet that diverted ditch flow over the road surface. Photo: Angela Wilson, Central Valley Regional Water Quality Control Board.

\section{RECOMMENDED ROAD MAINTENANCE PRACTICES}

Even properly designed and constructed roads need inspection and maintenance to function well and avoid road and environmental damage. Maintenance should be performed when needed. The longer the delay in needed maintenance, the more damage will occur and the more costly the repairs will be (fig. 14).

Maintenance should focus on correcting problems that may lead to road failure. This involves ensuring that the established drainage system is not compromised. Culverts plugged with debris often lead to ditch or stream water flowing on to the road surface, which can cause surface erosion or even wash away the entire road prism. Preventing such occurrences should be a top priority. Closing a road during the rainy season can reduce damage caused by vehicles and avoid substantial maintenance costs.

\section{KEY MAINTENANCE PRACTICES}

- Inspect roads regularly, especially before the winter season and following heavy rains.

- Keep ditches and culverts free from debris.

- Remove slide material from the road or ditches where it blocks normal drainage.

- Regrade and shape the road surface periodically to maintain proper surface drainage.

o Keep rolling dips shaped and graded.

o Keep the downhill side of the road free of berms unless they are intentionally placed to control water or traffic.

o As necessary, apply surfacing such as aggregate or pavement to protect the roadbed.

- Avoid disturbing soil and vegetation in ditches, shoulders, and on cut-and-fill slopes.

- Maintain an erosion-resistant surfacing such as grass or rock in ditches.

- Close the road during very wet conditions.

- Carry a shovel in your vehicle during the rainy season to clean out ditches, redirect water off the road surface, etc.

The key to good maintenance is identification of maintenance needs through frequent inspections. Road inspections should focus on identifying areas where problems may occur in future storms (fig. 15). All parts of the road including the road surface and cut-and-fill slopes should be inspected, as well as drainage structures such as culverts, bridges, and water bars. Ideally, inspections should be done in time to allow for repairs before the rainy season. 


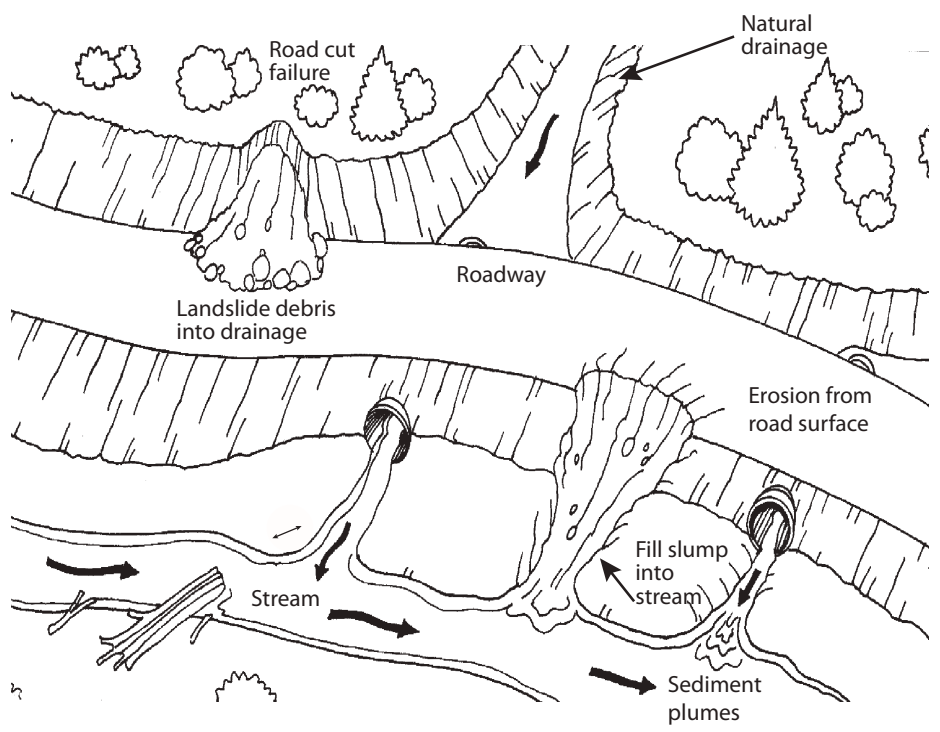

Figure 15. Road system problems to look for during a road inspection. Source: Keller and Sherar 2003.

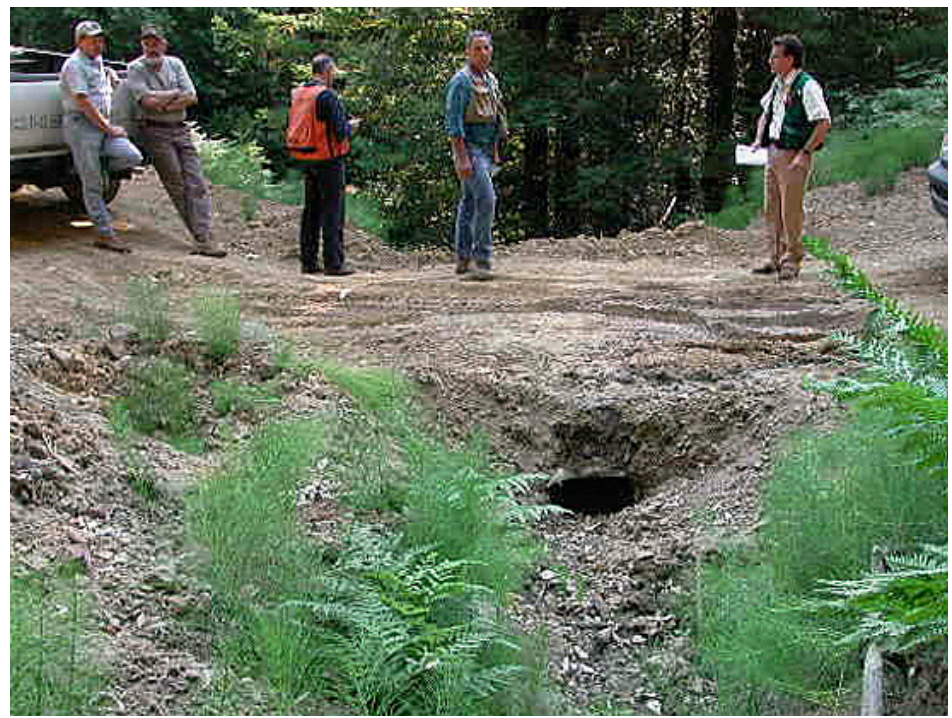

Figure 16. Culvert plugged with sediment at inlet. Photo: Angela Wilson, Central Valley Regional Water Quality Control Board.

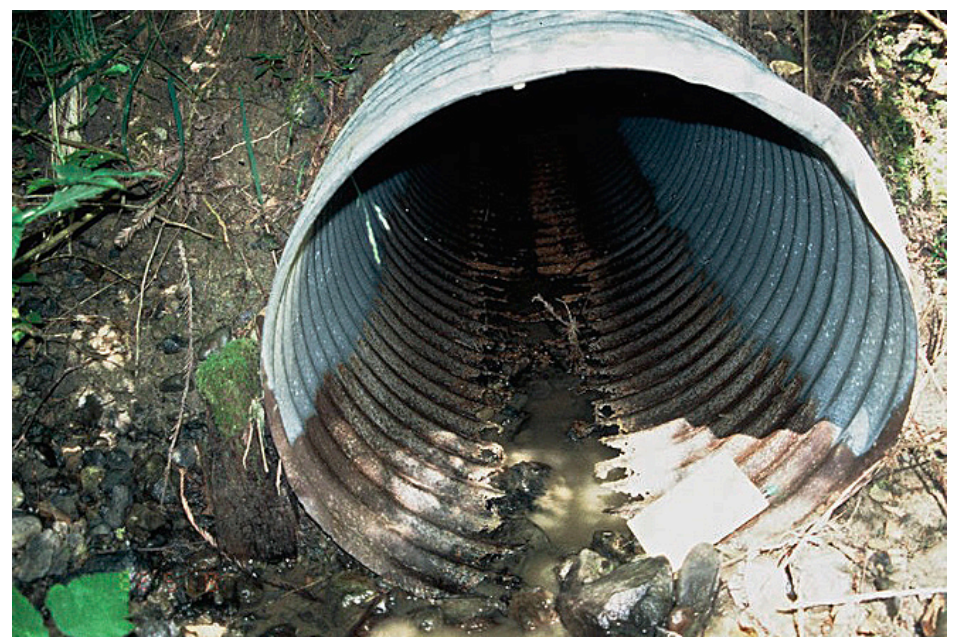

Figure 17. Culvert with rusted bottom and breakage caused by sediment. Photo: Angela Wilson, Central Valley Regional Water Quality Control Board.

\section{WHAT TO LOOK FOR DURING A ROAD INSPECTION}

- Culverts: Clear debris and sediment from culvert inlets (see figs. 16 and 17). Straighten bent culvert ends. If erosion has occurred at outlets, install energy dissipaters or armoring.

- Bridges: Inspect bridge abutments. Remove logs or branches lodged in the bridge structure.

- Water bars: Confirm that the water bars are working properly and directing drainage off the side of the road. Inspect the area downslope of the water bars for evidence of rills or gullies indicating that the slope requires additional protection from concentrated roadside drainage.

- Rolling dips: If erosion has occurred at the outside edge of the dip, install energy dissipaters or armoring.

- Inside ditches: Use a shovel to clear debris from the ditch. Avoid grading in ditches.

- Cut-and-fill slopes: Inspect for rilling, slumping, or cracks. Install more drainage structures if problems are found. Remove unstable material with an excavator.

\section{RECOGNIZING AND FIXING COMMON ROAD PROBLEMS}

Many road problems are quite easy to detect because they result in reduced driving comfort (e.g., rutting, potholes or wash boarding, erosion of portions of the roadbed, and deposition of soil on the road surface). Obvious problems such as these may cause impacts to streams and aquatic organisms by, for example, depositing sediment or creating barriers to fish passage. Road treatments can be designed to alleviate problems for traffic as well as aquatic habitat without much additional cost. Appropriate treatments for specific kinds of problems are identified here. Before initiating a treatment on your property, it is advisable to consult a professional erosion control or geotechnical specialist. 


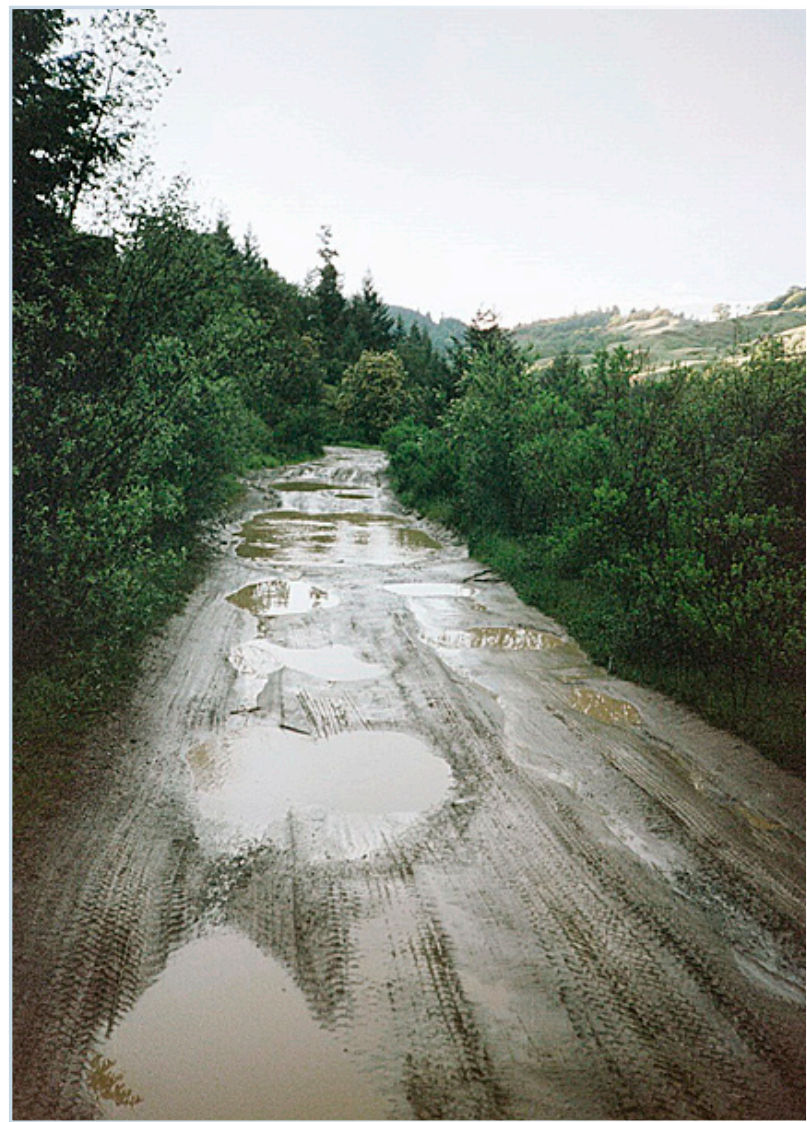

Figure 18. Water collecting on a forest road because of poor drainage. Photo: Jared Gerstein.

\section{Potholes, Gullies, Extensive Rilling, Mud, and Other Road Surface Problems}

\section{Symptom}

Potholes, ruts, and mud on the surface of the road are symptoms of drainage problems (fig. 18). A properly designed and maintained road will have very little standing or running water on the road surface, even during rain storms.

\section{Finding the underlying problem}

In order to locate the source of the problem, follow the water. Water may be originating from springs in the cut bank or under the road, from small creeks diverted onto the road surface, or from retained rain water due to improper drainage. The problem may also be caused by a combination of these.

First, look for springs on the cutbank or under the road. Water-loving vegetation, such as ferns or rushes, is a good indicator of the existence of springs. After a storm ends, puddles will dry out elsewhere on the road but remain much longer where you have springs. If no springs are found, look for streams diverting water onto the road surface. Small swales that are dry most of the year may flow during rain storms; go look for them while it is raining. Look for the original stream on the downhill side of the road.

If the road is retaining rain water on the surface during and shortly after rains, the road may need to be reshaped in order to drain water more efficiently. It is common for roads that have been poorly maintained for years to develop berms on one or both sides of the road, preventing water from draining from the road surface.

\section{Solutions}

Possible treatments for spring seepage onto roads are installing deeper inboard ditches and culverts to drain the water under the road, building up the road surface with base rock, or others as appropriate. Stream diversions onto the road surface may be treated by installing a culvert or rocked dip to place the stream back in its natural channel. Standing water due to poor drainage should be treated by changing the shape of the road to out-sloped, in-sloped, or crowned. Breach berms at strategic nonerosive locations to allow drainage and prevent their re-creation during grading. Out-sloping roads and installing rolling dips should be done whenever possible. Rock surfacing may also need to be added.

\section{Dysfunctional Ditches}

\section{Symptom}

One of the liabilities of a ditch system is the possibility of ditches plugging with debris, causing water to flow onto the road surface. Ditch water "captured" by the road surface can cause severe erosion (fig. 19) and even wash out the road completely.

\section{Finding the underlying problem}

Water may flow out of a ditch onto a road when the capacity of the ditch is exceeded. This occurs when the volume of runoff exceeds the ditch capacity or, more commonly, when a ditch relief culvert is plugged with debris. In the latter instance, the plugged cul- 


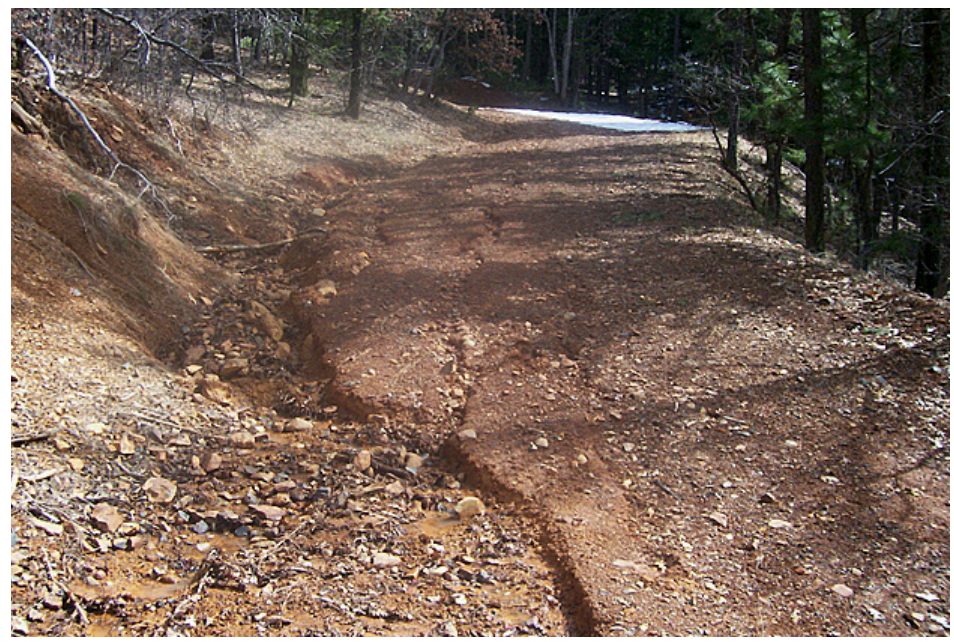

Figure 19. Erosion caused by ditch water leaving the ditch and traveling across the road. Photo: Susan Kocher.

vert may be located at the point where water flows onto the road or it may be uphill from there. Once the plugged culvert is located, examine its size and alignment. If a culvert plugs regularly, especially with sediment, there may be a design problem. If the culvert is less than 18 inches in diameter, it may be too small. If the culvert is installed at too sharp of an angle at the inlet, ditch water may not be directed into the culvert at high flow. If the crossdrain grade is too flat, sediment may settle out in the culvert rather than passing through it, causing blockage.

\section{Solution}

Once the plugged culvert is located, material blocking the culvert inlet should be removed. If this is the first time the culvert has plugged and the blockage was caused by a recently fallen tree or branch, simply removing the blockage may be sufficient. If the culvert repeatedly plugs, it may be undersized or misaligned and need to be replaced or realigned. In some cases, excess sediment may be evidence of upslope instabilities that need to be addressed.

\section{Symptom}

Another liability of ditch systems can be inadequate cross drains. Without a sufficient number of cross drains or ditch relief culverts, ditch water may become increasingly concentrated, gain erosive power, and cause ditch erosion in larger storms. Deeply incised ditches can be a hazard to driving, especially when they become large enough to accommodate a car tire (fig. 20).

\section{Finding the underlying problem}

Ditches incise when they carry too much flow for their design capacity and they erode rather than spill water out onto the road. Too much flow in the ditch occurs because there are not enough ditch relief structures and/or because there are sources of water other than road runoff contributing to ditch flow. Examine the ditch system to see if the ditch has captured the flow from a stream channel or spring and diverted it down the ditch. If not, the most likely problem is too few ditch relief culverts or cross drains.

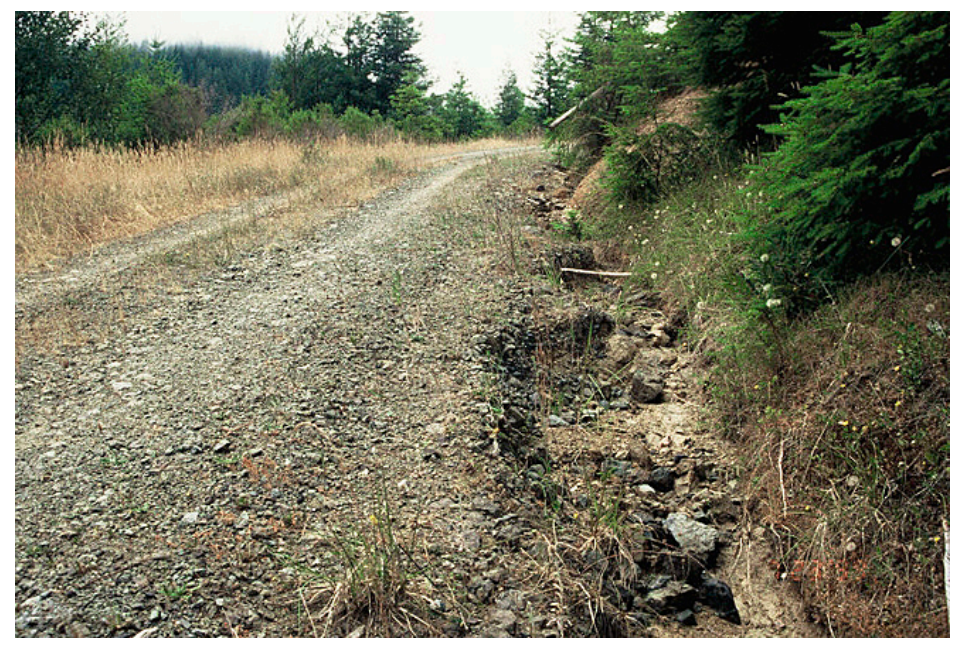

Figure 20. Eroding inboard ditch on an in-sloped road. This is a symptom of inadequate cross drains for conveying ditch flow across the road. Photo: Richard Harris.

\section{Solution}

Ditch-captured stream channels should be treated by installing a culvert under the road and reconnecting the stream channel to its original course below the road. Problems arising from inadequate drainage should be treated by adding more ditch relief culverts. A more effective long-term solution may be to out-slope the road, if feasible, and remove the ditch altogether. Armoring ditches without treating the underlying drainage problem may reduce erosion in the short term but is not considered a permanent solution.

\section{Symptom}

Ditches may become filled in with sediment, rock, or woody debris (fig. 21). This reduces their 


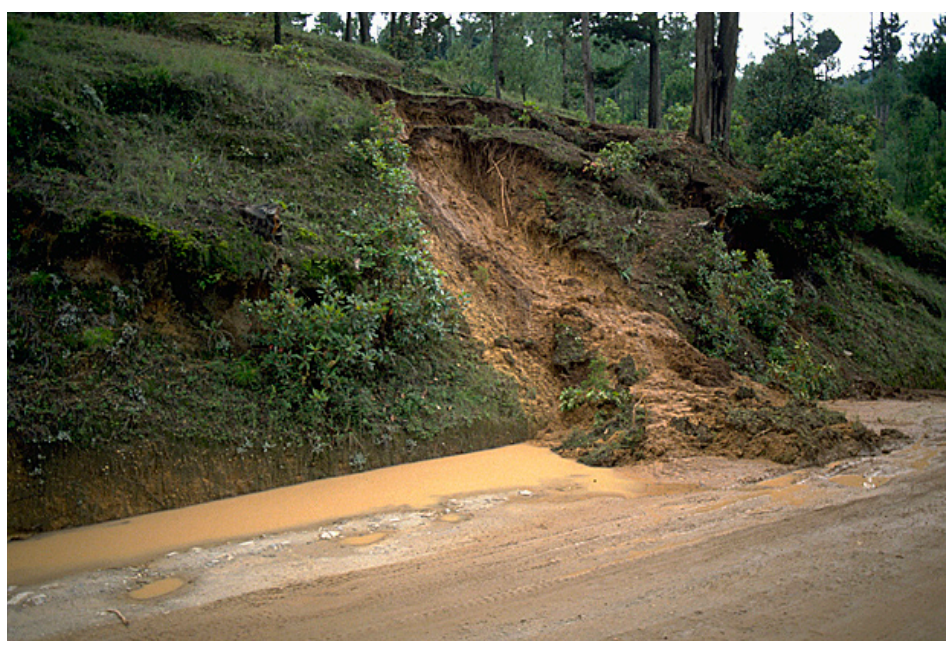

Figure 21. Cut bank failure blocking inboard ditch. Cut bank failures cause operational and maintenance problems, especially when chronic. Source: Keller and Sherar 2003.

capacity to convey ditch flow. The inlets to ditch relief culverts can become filled with sediment, causing ditch water to flow over and erode the road surface.

\section{Finding the underlying problem}

Examine the cut slope along the road to identify the source of the sediment. A slump or failure in the cut slope may have delivered dirt and rocks to the ditch. Or, a tree or branch may have fallen into the ditch, causing sediment to accumulate. Sediment may have accumulated in sections of ditch that have a flat gradient.

\section{Solution}

Filled-in ditches should be cleaned out with hand tools or heavy equipment, depending on the scale of the problem. If this is a recurring problem, the cut slope may need treatment to reduce its chances of slumping. A number of slope stabilization techniques are available and can be developed with the help of a professional erosion control or geotechnical specialist. Road surface sediment can be reduced by rocking the road. A ditch relief culvert may need to be installed before the grade flattens out, to carry water through the culvert before the sediment settles out in the ditch.

\section{Gullies Caused by Roads}

\section{Symptom}

Gullies are caused when increased or concentrated flow from the road system flows onto erosive soil. Most often, gullies originate from a road system's drainage features. They can be identified by their bare dirt banks and occurrence in places where natural streams do not occur, such as smooth hillslopes or ridges (fig. 22). Gullies may or may not threaten the roadbed itself, but they are always a significant source of sediment and thus a detriment to streams.

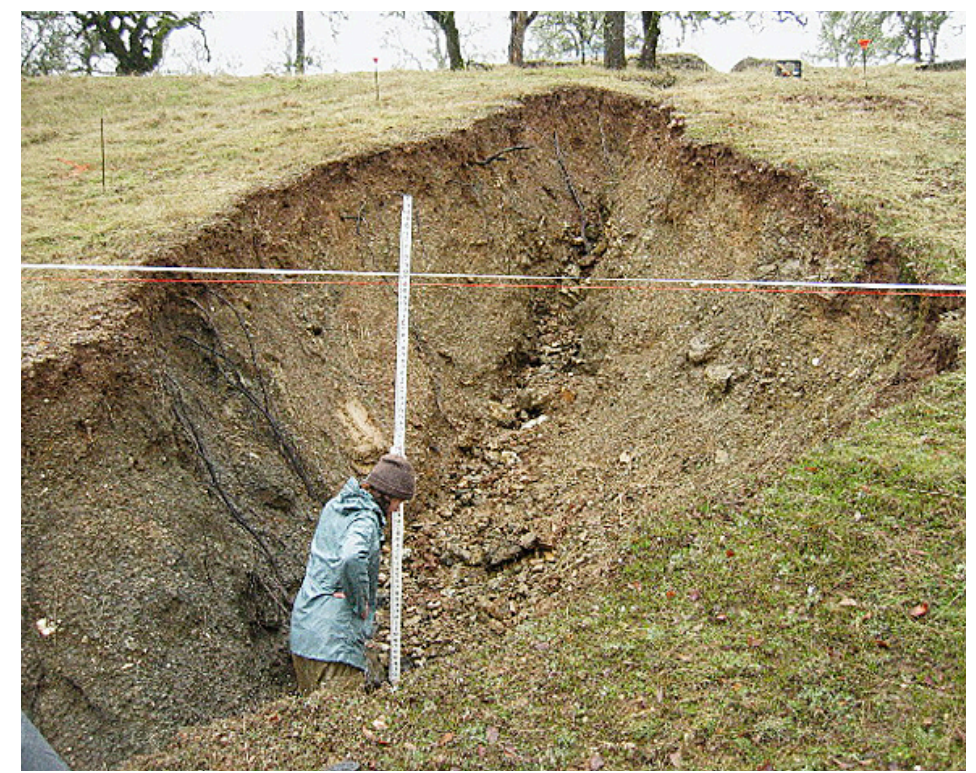

Figure 22. Gully caused by through-cut on road at base of steep road section. Photo: Jared Gerstein.

\section{Finding the underlying problem}

Inspect for gullies at the outlets of ditch relief culverts and rolling dips or where inboard ditches leave the road at a corner. Most gullies are caused by a concentration of water from the road and ditch system. Walk the road system to identify the drainage structures releasing flow that leads to gullies. Gullies can also occur when a stream has been diverted out of its natural channel. If this is the case, it is important to locate the original stream channel by walking up the gully to find where it starts.

Another cause of gullies can be culverts that have been installed improperly, with outlets set on the hillside rather than back in the natural channel. Examine culverts located at the origin of the gully flow to see if misalignment is causing the erosion. 


\section{Solution}

The solution to gullies is to remove the concentrated flow from the soil it is eroding. Gullies should be dewatered by returning the flow to a controlled conveyance, either back into the ditch or stream system from which the flow escaped, or by realigning the culvert that allowed its escape. Alternatively, flow can be rerouted around the most erosive soils by installing downspouts. The goal of the treatment is typically to stabilize the gully and halt further erosion since it usually is not feasible or cost effective to fill in and restore a gully's original slope.

\section{Stream Crossings}

Stream crossings on roads can be the most significant source of sediment to streams. They are also the most likely locations to become impassable during a storm. Because of their importance to both stream health and accessibility, these sites should be carefully watched and maintained. Typical problems include culvert plugging, fill eroding, outlet scouring, and blocking of the migration of fish and other aquatic life such as amphibians.

\section{Symptom}

Culverts that convey streams under roads must be large enough to transport the flow plus the tree branches, sediment, and rocks that often accompany the flow during large rain storms (fig. 23). Stream culverts may plug when debris blocks the inlet, allowing water to overtop the crossing and possibly wash out the crossing and road altogether.

\section{Finding the underlying problem}

Culverts that plug frequently with debris may be undersized for the flow of the stream and the debris it carries, or they may be misaligned, blocking the flow of water and debris through the culvert. When material collects behind a culvert, it is likely that the culvert is too small.

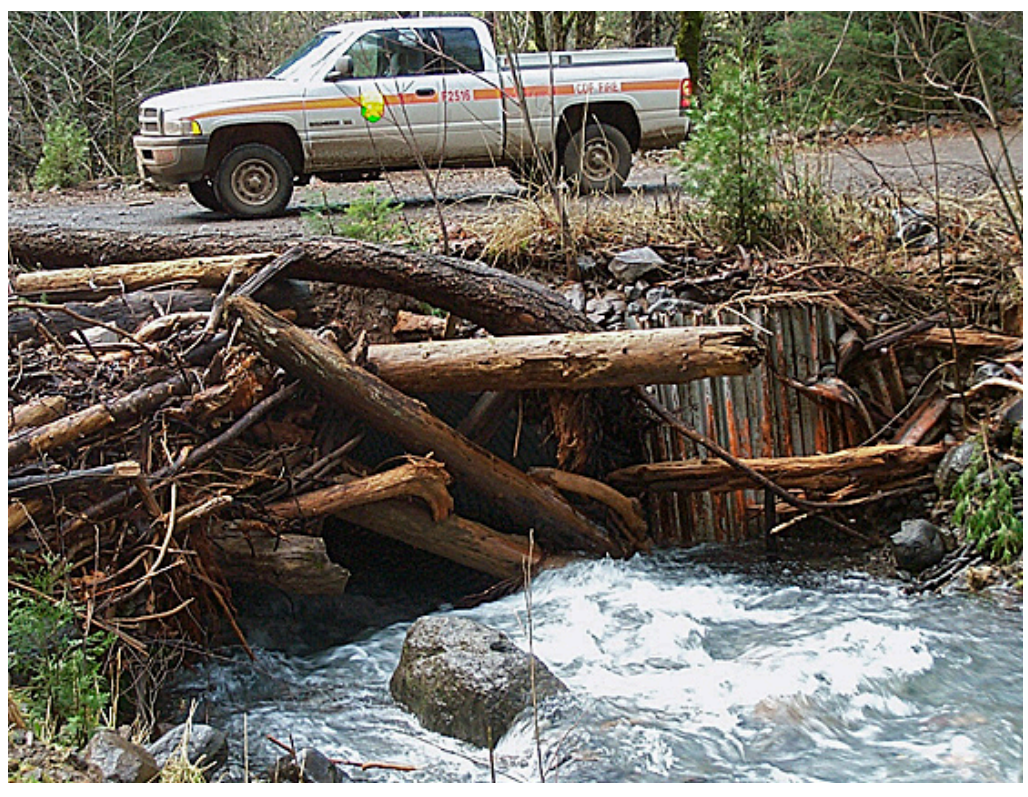

Figure 23. This culvert is nearly plugged by woody debris, endangering the road. Photo: Angela Wilson, Central Valley Regional Water Quality Control Board.

\section{Solution}

The ideal treatment for an undersized culvert is replacement with a larger one, capable of carrying flow and debris. Appropriately sizing a culvert for the stream and watershed it drains is a fairly technical task and should be done by a knowledgeable professional (Cafferata et al. 2004). In some relatively simple cases, it may be feasible to install trash and debris racks upstream from the culvert to capture and retain the debris so that it does not flow into the culvert (fig. 24). This, however, should be discouraged on fish-bearing watercourses because debris accumulations may become a barrier to migrating fish. Remember that debris racks need to be cleaned regularly to continue to function.

\section{Symptom}

Installing a culvert to convey a stream under a road involves placing a significant amount 


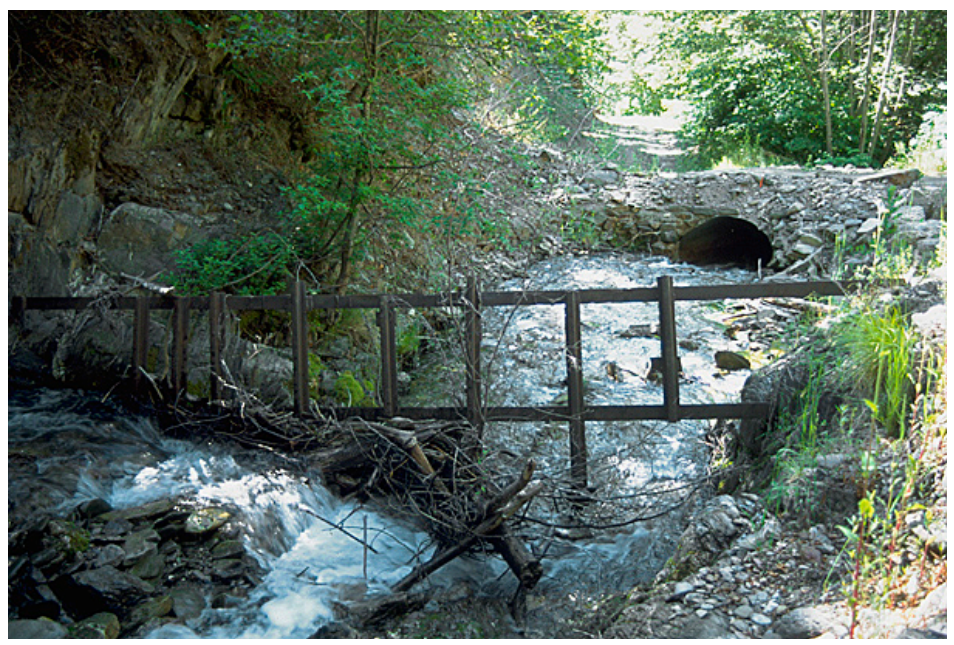

Figure 24. A trash rack installed upstream to protect a culvert from plugging. Source: Keller and Sherar 2003.

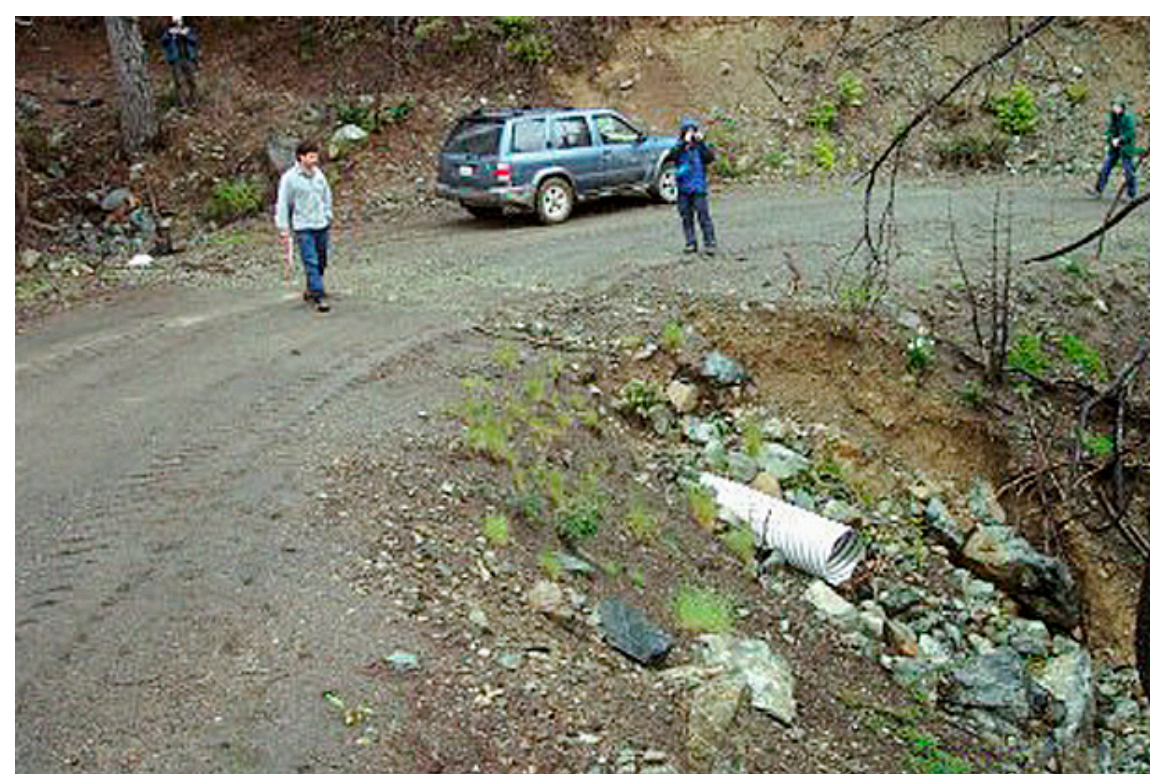

Figure 25. Eroding fill slope and culvert failure due to plugging at inlet and diversion of flow across the road. Photo: Bill Weaver, Pacific Watershed Associates. of fill in the channel above and below the culvert, and then building the road base on that fill. The fill over the culvert may erode, narrowing the traveled way (fig. 25).

\section{Finding the underlying problem}

Road fill is most often eroded by water plunging from the outlet of a culvert that is too short. "Shotgun" culverts shoot the water down to the streambed while eroding the fill under the culvert. Inspect road culverts at the downslope ends, looking for any that stick out into the air rather than carry their flow to the base of the fill slope.

\section{Solution}

The most thorough solution to shotgun culverts is to replace them with longer pipes that are placed at the grade of the natural stream channel rather than high in the fill above the stream. Alternatively, a downspout or rock armor can be added below the outlet if erosion has not been too severe (fig. 26).

\section{Symptom}

Culverts may create barriers to fish migration (fig. 27). Problems include excessive water velocity, insufficient water depth, lack of a downstream jump pool, and excessive jump height. Culverts that are relatively
Figure 26. Rock armoring at ditch relief culvert outfall to reduce potential for downstream erosion. Note also the berm around the fill slope to prevent road runoff from eroding it. Also, straw mulch has been placed on the fill slope to reduce erosion. Photo: Jared Gerstein.

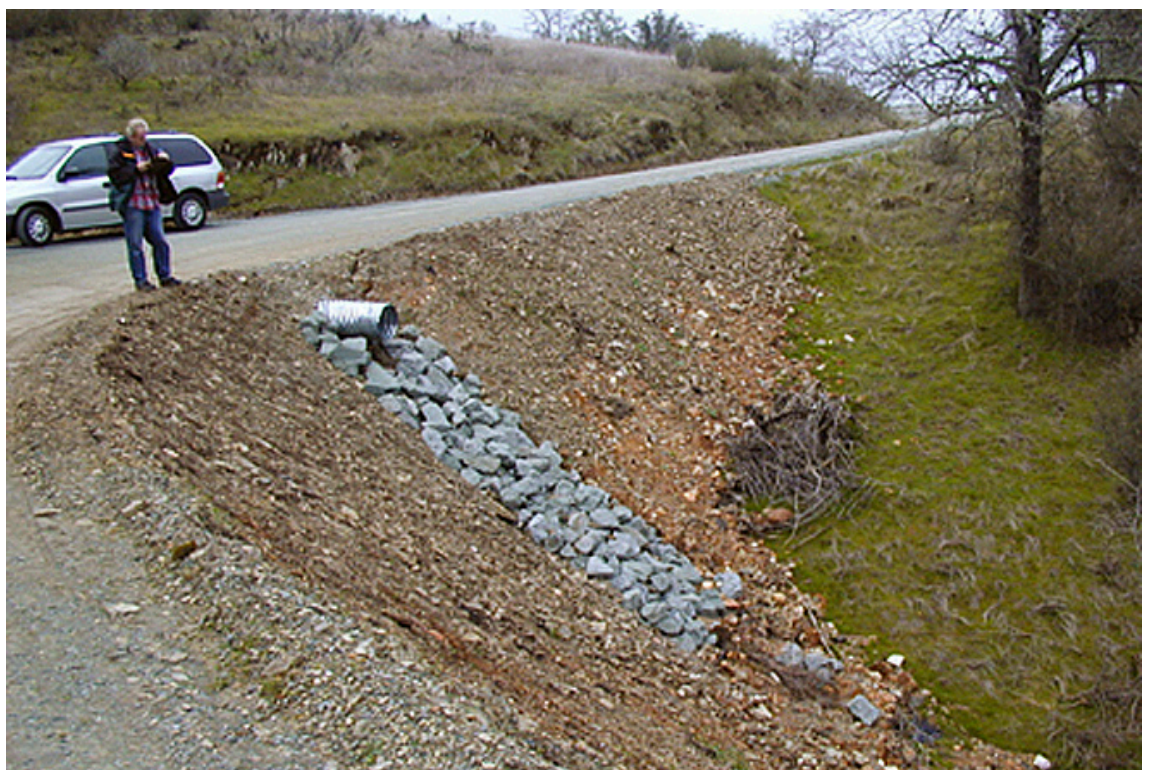



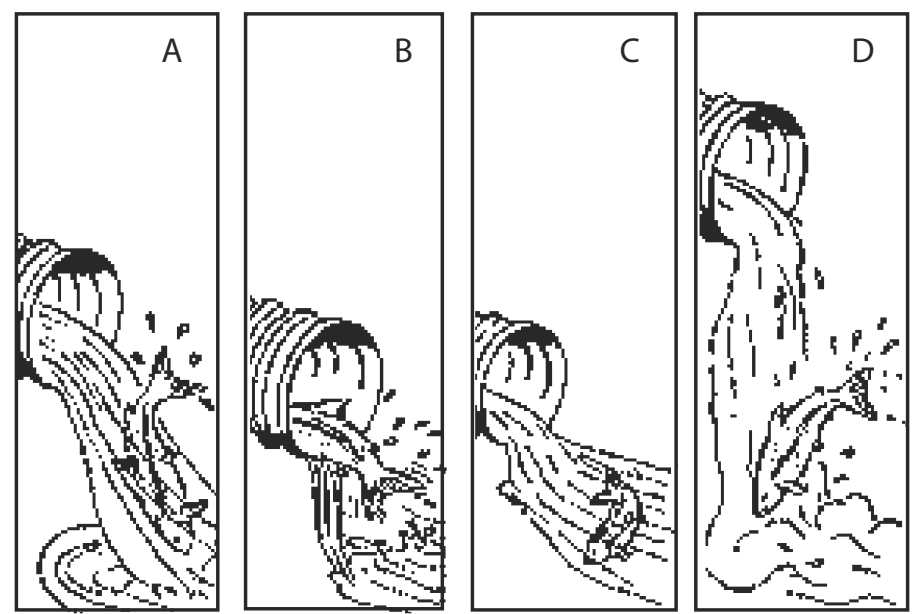

Figure 27. Barriers to fish migration caused by culverts. Source: Keller and Sherar 2003.

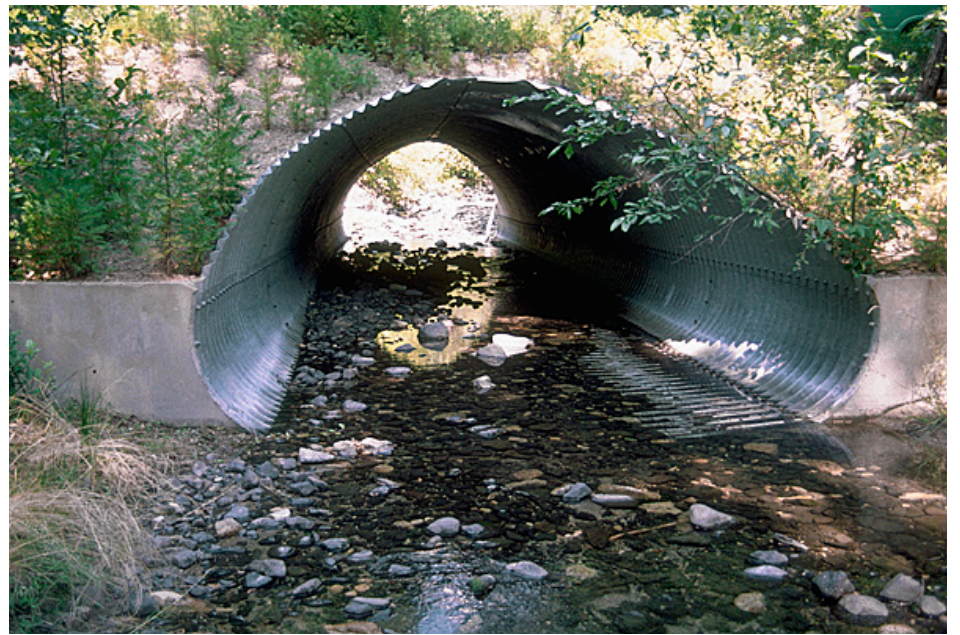

Figure 28. An arched pipe installed on a fish-bearing stream to minimize impacts on fish habitat and migration. Source: Keller and Sherar 2003. problems will be quite obvious. Unfortunately, many are not. Therefore, the best way to identify whether your crossings are blocking fish is to consult a fisheries biologist from a state, federal, or local agency.

\section{Solution}

Replacement of problem culverts with bridges and arched culverts of adequate size is preferred because they modify the channel less and so avoid many problems that can block migration (fig. 28). Appropriate assistance should be sought in designing and constructing crossings where migrating fish must be accommodated. Contact your local Department of Fish and Game office. In some cases, passage through existing culverts may be improved by installing baffles or weirs to slow and funnel stream water. In other cases, the upstream and/or downstream channels may be modified to create resting pools and reduce the jump height.

\section{GETTING ROAD WORK DONE}

There are some things that a landowner can do to maintain his or her roads and there are other actions that are best left to professionals. If you are contemplating new road construction or major road upgrading and you are not experienced with this work, you need to get help. County public works and planning departments, your local California Department of Forestry and Fire Protection or Resource Conservation District office, UC Cooperative Extension Office, and your neighbors may be able to recommend someone who can help you plan and implement a road construction or improvement project. Depending on your location and the type of work, you may even qualify for grants and cost sharing programs (see "Sources").

Before undertaking extensive road work, it is important to have a good plan. You may retain professionals trained in road assessment to evaluate your roads in relation to your land management and use objectives. The objectives might be to reduce maintenance costs, to reduce sediment production, to protect natural resources, or to 


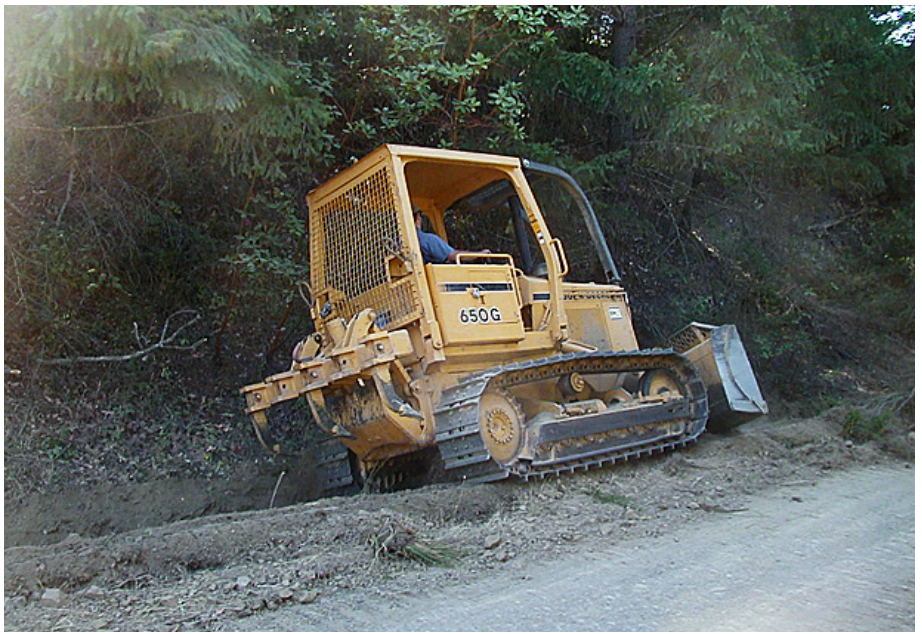

Figure 29. Bulldozer clearing out a road ditch. Photo: Jared Gerstein.

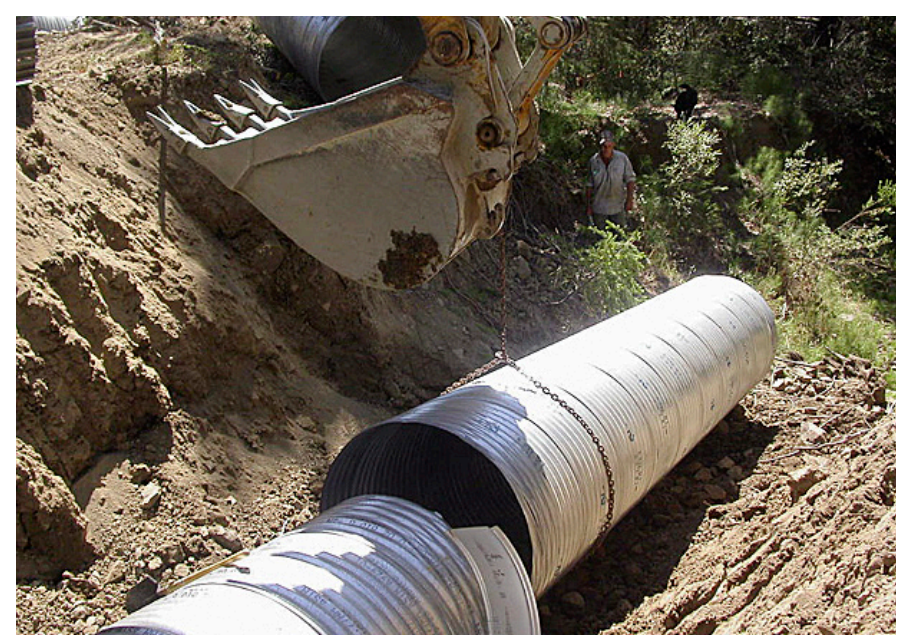

Figure 30. Installation of a new culvert after the old one was excavated. Photo: Jared Gerstein.

assure accessibility in all conditions. A road assessment may be used to help decide whether a road is worth maintaining in its current condition and location. Many roads were built in locations because of property boundaries, with little regard for geologic, geomorphic, biologic, or hydrologic conditions. If the road is tied to an easement and there are multiple landowners, relocation may not be an option. If a road is a chronic problem, however, relocation should be considered because it may be the cheapest and most effective remedy. A thorough road assessment will help you decide the best course of action and develop a plan for implementing road work.

Constructing or upgrading a road may require the services of a licensed civil engineer. Especially difficult projects may require other professionals including a licensed geologist or structural engineer. Simpler projects may only require a qualified equipment operator or grading contractor. When choosing an engineer or a contractor, it is important to carefully review their qualifications to do the work, their experience, and their ability to perform on time and on budget. Always ask for references and always follow up by checking them. Never hire someone who is not adequately insured against liabilities resulting from the work. You also want to make sure your contractor is licensed. Get the contractor's license number, and check with the State Contractors Licensing Board to see if there are any complaints or violations for the operator you intend to hire.

Routine road maintenance is another matter and there are many things you can do to ensure that your roads function well under all weather conditions. In some instances when a road is shared by several landowners, there may already be a road association or homeowners' association that is responsible for road maintenance. Generally, if you do not know if you are part of a road association, you probably are not. Road and homeowners' associations assess landowners a fee used to offset costs for road maintenance. The fee is either paid on a yearly basis or as the need for maintenance arises. If you have a neglected road that serves several properties and there is no road maintenance agreement between them, you might consider initiating one. One of the major problems in rural areas is "orphan roads" that no one takes responsibility for maintaining.

For the roads on your property that are your sole responsibility, the key to good maintenance is a system of inspection and record-keeping. Inspections should be performed on all your roads and stream crossings before the winter, during storm events, and after the winter. Use the diagnostic tips previously described to identify 
maintenance needs. Simple tasks such as culvert and ditch clearing can be performed by most landowners (fig. 29). More complex tasks, such as roadside brushing, remedial grading repair, or installation of culverts (fig. 30), will probably require outside assistance. Keeping good maintenance records can help landowners evaluate the cost of correcting on-going problems and judge whether road upgrading projects would be cost effective. It is also essential for tax purposes.

\section{ELEMENTS OF GOOD ROAD MAINTENANCE RECORD KEEPING}

- Identify and prepare sketch maps of problem areas and treatments applied.

- For each site, describe the problem, when it started, and what caused it.

- Document the things done to fix the problem.

- List the equipment and labor hours needed to fix the problem.

- Quantify the amount of armor or rock imported to fix the problem (cubic yards).

- Quantify the amount of sediment or spoils removed (cubic yards).

- Measure the length, width, and depth of any erosion features.

- Take photos before and after the maintenance activities.

\section{PERMITS FOR ROAD WORK}

Depending on where you live, extensive road work may require a grading permit from the county public works or planning department, particularly if the project involves new road construction. Not all counties have grading ordinances but all have stipulations in their building codes that apply to grading for home sites and driveways. These are typically triggered by the extent of planned disturbance. Before undertaking any grading on your property, check with your county planning staff.

If you are planning on crossing or otherwise altering a stream or creek, you may be required to obtain a Streambed Alteration Agreement from the California Department of Fish and Game. Activities requiring these agreements include installing culverts, bridges, or fords; rip-rapping the banks of stream channels; or skidding logs across temporary crossings. Many projects that require a Streambed Alteration Agreement will also require a permit from the U.S. Army Corps of Engineers. If the project involves a stream that has anadromous fish (i.e., salmon, cutthroat trout, or steelhead), additional consultation or permits may be required from the National Marine Fisheries Service or from the U.S. Fish and Wildlife Service. Your local

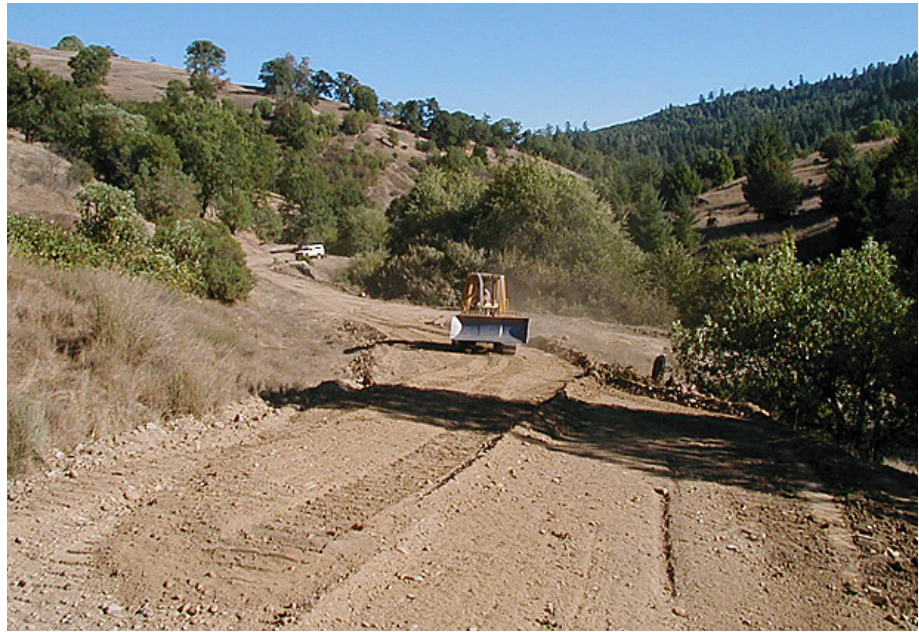

Figure 31. Bulldozer reshaping road surface to out-sloped condition to improve drainage. Photo: Jared Gerstein.
Department of Fish and Game staff should be aware of the permit requirements of these agencies.

\section{ESTABLISHING A WRITTEN CONTRACT FOR ROAD WORK}

Landowners should establish a clear written contract for contractors providing road services. Contracts should include the necessary road specifications and standards to be constructed or maintained. The various parts of a new road to be constructed should be listed, including the subgrade and surface and the cutand-fill slope. The standards to which these should be built, including the width of the subgrade and surface, slope of cut and fill, and depth and size of the base and surface rock, should be specified. 


\section{TYPES OF EQUIPMENT USED IN ROAD MAINTENANCE}

A variety of heavy equipment may be used when constructing or maintaining a road. Bulldozers are often used to make road cuts, shape the road, and develop the subgrade (fig. 31). Excavators can be used to replace crossings and develop new road alignments (fig. 32). Backhoes have many uses, including replacing small crossings, loading rock, and road shaping. Graders are used for final road shaping, spreading surface rock, and smoothing the surface (fig. 33). Dump trucks are used to transport rock to the construction site and to haul away any excess cut materials (fig. 33). Rollers are specialized to roll over the road surface and compact rock and road materials.

\section{ROAD WORK COSTS}

Upgrading an existing road is less expensive than constructing a new one, but may still involve substantial costs. Cost depends on the heavy equipment used, hourly equipment rental or contract rates, the skill and experience of the operator, design standards of the road, and the choice of the specific drainage structures and features to be installed. Examples of costs for road improvements are listed in table 3. When

Table 3. Costs to modify and improve existing roads

\begin{tabular}{|c|c|c|c|c|}
\hline Activity & Ideal equipment & Cost rate* & Production rates $^{\dagger}$ & Costs \\
\hline out-sloping road and filling ditch & motor grader with rippers & $\$ 140 / \mathrm{hr}$ & $500 \mathrm{ft} / \mathrm{hr}$ for a $20 \mathrm{ft}$ wide road & $\$ 280 / 1,000 \mathrm{ft}$ \\
\hline installing rolling dip & $\begin{array}{l}\text { small dozer with rippers } \\
\text { (John Deere } 450 \text { ) }\end{array}$ & $\$ 130 / \mathrm{hr}$ & $\begin{array}{l}1 \mathrm{hr} \text { each (30 to } 40 \mathrm{ft} \text { long on flat roads) } \\
2 \mathrm{hr} \text { each ( } 50 \text { to } 100 \mathrm{ft} \text { long on steep roads) }\end{array}$ & $\$ 130$ to $\$ 260$ each \\
\hline removing berm or cleaning ditch & motor grader & $\$ 140 / \mathrm{hr}$ & $1,000 \mathrm{ft} / \mathrm{hr}$ & $\$ 140 / 1,000 \mathrm{ft}$ \\
\hline $\begin{array}{l}\text { rock-surfacing road ( } 1.5 \text { in. minus } \\
\text { crushed) }\end{array}$ & dump truck spread & $\begin{array}{r}\$ 25 \text { to } \$ 50 / \mathrm{yd}^{3} \\
\text { delivered }^{+}\end{array}$ & 4 in. deep $\times 20 \mathrm{ft}$ wide $=250 \mathrm{yd}^{3} / 1,000 \mathrm{ft}$ road & $\begin{array}{l}\$ 6,250 \text { to } \$ 12,500 / 1,000 \\
\mathrm{ft}\end{array}$ \\
\hline $\begin{array}{l}\text { installing ditch relief culvert ( } 40 \mathrm{ft} \\
\text { of } 18 \text { in. culvert) }\end{array}$ & $\begin{array}{l}\text { backhoe or tractor, } \\
\text { laborer }\end{array}$ & $\begin{array}{r}\$ 120 / \mathrm{hr} \text { or } \\
\$ 95 / \mathrm{hr} \\
\$ 55 / \mathrm{hr}\end{array}$ & $\begin{array}{l}3 \mathrm{hr} \text { each + culvert }(\$ 35 / \mathrm{ft}+\$ 25 \text { coupler }+\$ 165 \\
\text { labor) }\end{array}$ & $\$ 1,950$ each \\
\hline $\begin{array}{l}\text { installing stream crossing ( } 36 \text { in. } \times \\
40 \mathrm{ft} \text { culvert with } 200 \mathrm{yd}^{3} \text { fill) }\end{array}$ & $\begin{array}{l}\text { excavator, } \\
\text { small dozer, } \\
\text { water truck, } \\
\text { laborer }\end{array}$ & $\begin{array}{r}\$ 175 / \mathrm{hr} \\
\$ 130 / \mathrm{hr} \\
\$ 95 / \mathrm{hr} \\
\$ 55 / \mathrm{hr}\end{array}$ & $\begin{array}{l}\$ 2,350 \text { culvert (w/coupler) }+\$ 1,225 \text { excavator }+\$ 910 \\
\text { dozer }+\$ 190 \text { water truck }+\$ 165 \text { labor }+\$ 125 \\
\text { tamper }\end{array}$ & $\$ 4,965$ each \\
\hline installing culvert downspout & $\begin{array}{l}\text { hand labor, } \\
\text { equipment (>24 in. culvert) }\end{array}$ & $\begin{array}{r}\$ 55 / \mathrm{hr} \\
\$ 125 / \mathrm{hr}\end{array}$ & $\begin{array}{l}2 \mathrm{hr} \text { labor for } 20 \mathrm{ft} \times 24 \mathrm{in} .3 \mathrm{hr} \text { labor for } 40 \mathrm{ft} \times 36 \\
\text { in. }\end{array}$ & $\begin{array}{l}\$ 110+\text { materials } \\
\$ 375+\text { materials }\end{array}$ \\
\hline straw mulching of bare soils areas & labor & $\begin{array}{r}\$ 55 / \mathrm{hr} \\
\$ 7.50 / \text { straw bale } \\
\text { incl. tax/delivery }\end{array}$ & 1 bale/600 $\mathrm{ft}^{2}$ to $700 \mathrm{ft}^{2}+$ spreading at 4 bales $/ \mathrm{hr}$ & $\$ 36$ to $\$ 40 / 1,000 \mathrm{ft}^{2}$ \\
\hline upgrading road completely & $\begin{array}{l}\text { motor grader, } \\
\text { skip loader, } \\
\text { dump truck } \\
\text { water truck } \\
\text { riding compactor }\end{array}$ & $\begin{array}{r}\$ 140 / \mathrm{hr} \\
\$ 110 / \mathrm{hr} \\
\$ 85 / \mathrm{hr} \\
\$ 95 / \mathrm{hr} \\
\$ 95 / \mathrm{hr}\end{array}$ & $\begin{array}{l}\text { Average mid-slope road requiring stream crossing } \\
\text { upgrades }\end{array}$ & $\begin{array}{l}\$ 45,000 \text { to } \$ 77,000 \\
\text { per } \mathrm{mi}\end{array}$ \\
\hline
\end{tabular}

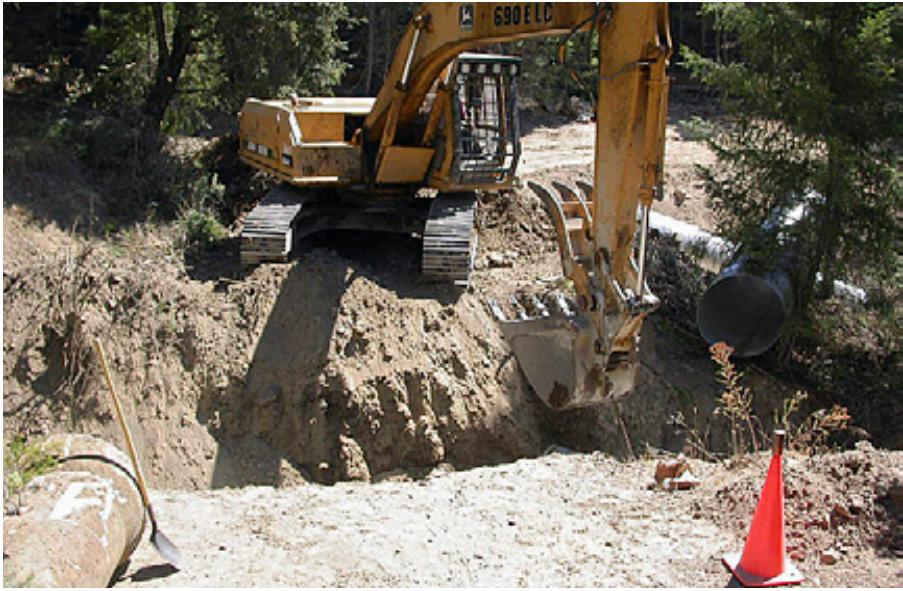

Figure 32. Excavator removing a crossing, including culvert and fill. Photo: Jared Gerstein.

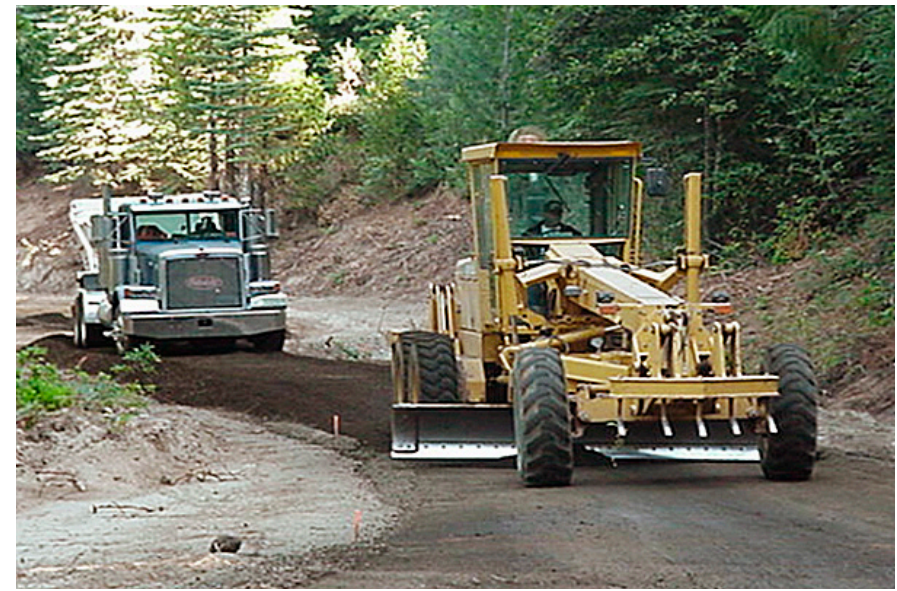

Figure 33. A grader spreading the gravel on the road surface placed by a dump truck. Source: Joe Hoffman, Plumas National Forest. 


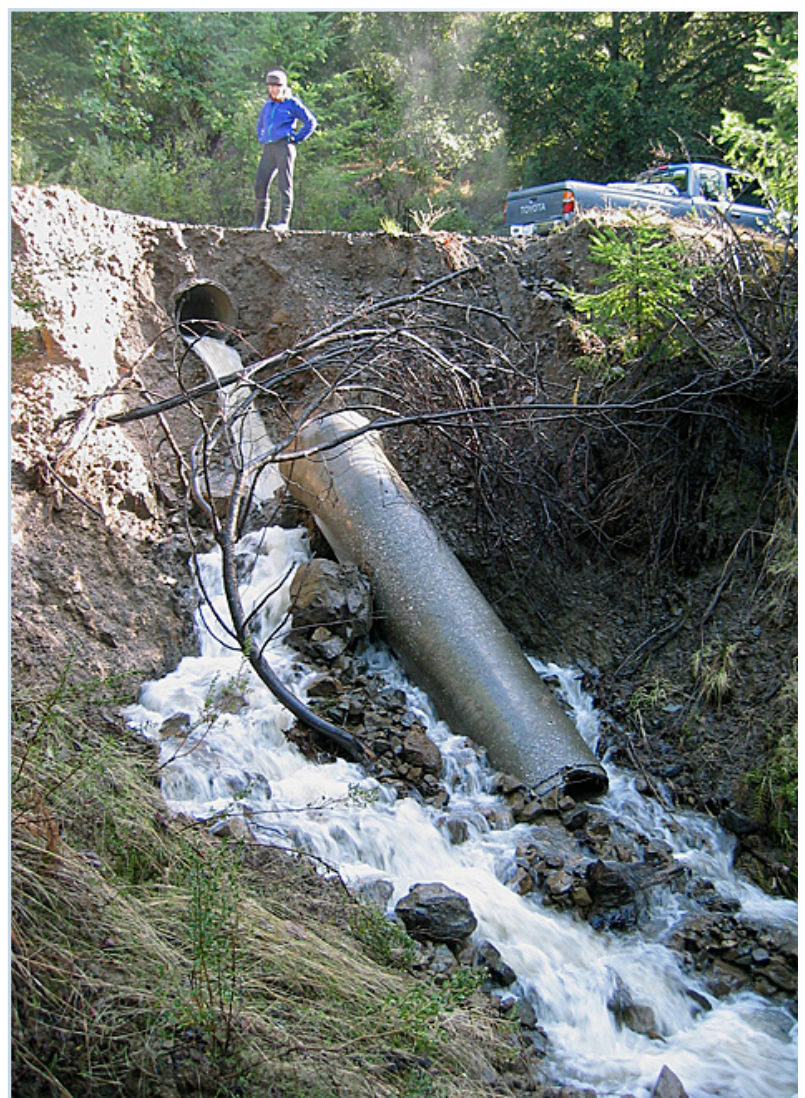

Figure 34. Outlet of a concrete culvert (30 inches in diameter) before the project. The culvert was placed too high in the fill, resulting in a 10-foot drop to the channel at the outlet. This caused erosion of the road fill and stream banks, eventually undermining the outer section of the culvert. Photo: Jared Gerstein.

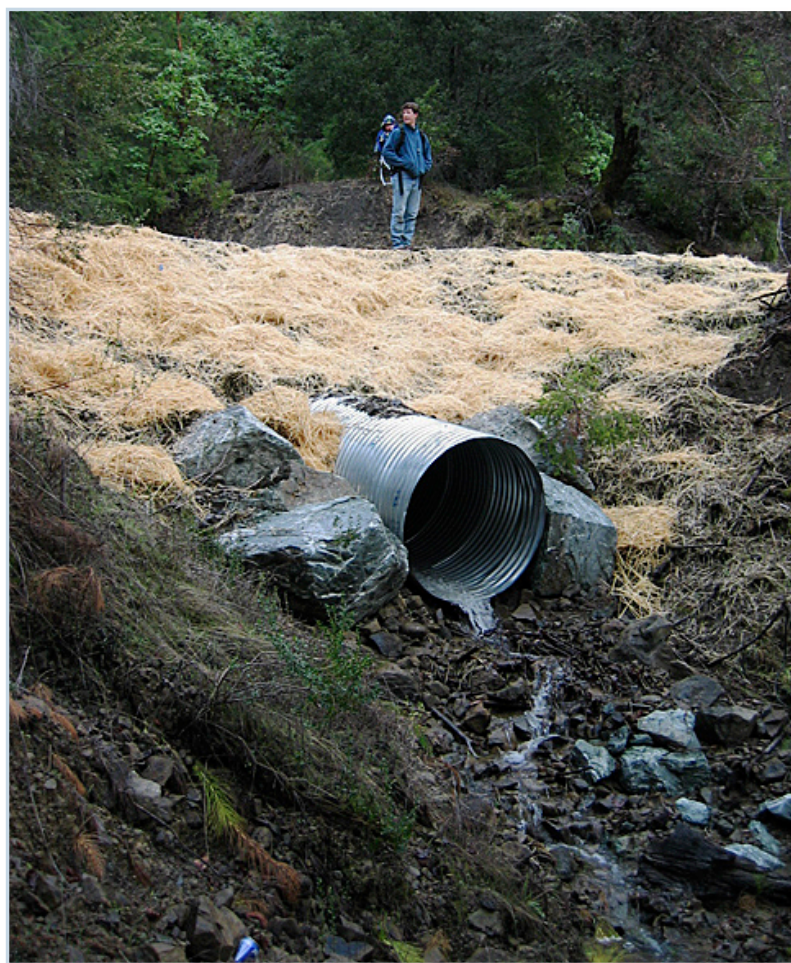

Figure 35. The culvert was replaced with a metal pipe (48 inches in diameter) at the correct slope. The road surface was lowered, reducing the fill volume by 100 cubic yards. The outlet and fill were armored to prevent future diversion. Photo: Jared Gerstein. using different equipment, the rates for some treatments may differ from those listed here. Tasks accomplished by manual labor, such as culvert downspout installation and straw mulching for erosion control, are much less expensive than tasks requiring heavy equipment. Installing rolling dips is substantially less expensive than installing ditch relief culverts because only one type of equipment and one worker is needed, and there is no culvert to purchase. The most expensive aspect of building or upgrading a permanent rural road is placing rock on the roadbed and road surface. The drainage structures and road shaping need to be done first, but rock surfacing is the final ingredient necessary to make the road durable for year-round travel.

\section{ROAD WORK CASE STUDIES}

Some examples of road upgrading projects are described below. These projects were undertaken by private landowners, the U.S. Forest Service, and the University of California.

\section{Tom Long Watershed}

The Tom Long Watershed in Humboldt County is like many other rural areas that have been subdivided for residential use. The road system was put in for harvesting timber during the 1950s and '60s. Harvesting was only done during the dry season and roads were only intended to handle seasonal access. In the 1970 s the watershed was subdivided into 40-acre parcels with the layout based largely on the location of the original logging roads. No formal road association or methods for funding road betterment or maintenance were established in the subdivision process. After the subdivision, roads were maintained on an emergency basis, meaning that bridges and culverts were only replaced if the road was no longer passable. Roads were rarely graded and rock surfacing was seldom if ever applied. The watershed became notorious for some of the worst roads in the region.

In the late 1990s residents organized in response to the threat of increased water quality regulation and out of exasperation with degraded road conditions. Following an evaluation of the road system, a number of sites were identified for remedial treatment. The highest priority sites were problem roads and crossings nearest the fish-bearing reaches of Tom Long Creek (figs. 34 and 35). Eventually, remedial work included replacing and upgrading 17 culverts and fixing two active creek diversions at a cost of approximately $\$ 120,000$. The majority of the work was funded with a combination of local, state, and federal grant dollars intended to improve fisheries and water quality conditions.

These efforts addressed major issues, but road surfacing, drainage, and other needed improvements have not been completed. All this work requires funding, especially for equipment operators, and funds available from grant programs are limited. Gradually, the work will get accom- 


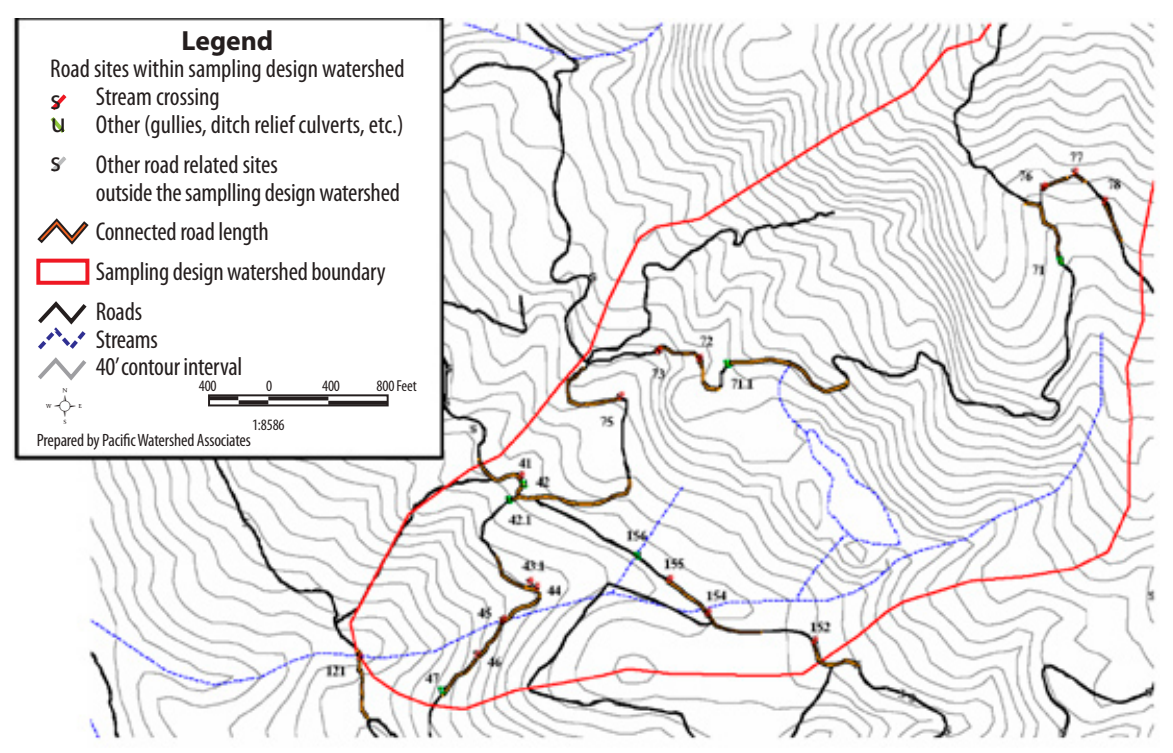

Figure 36. Road upgrading sites at the experimental watershed, Hopland Field Research and Extension Station. Source: Bill Weaver, Pacific Watershed Associates. plished. As one resident said, "The grant resources enabled us to complete the root canals in the watershed and now we have to find the money to pay for the routine cleanings."

\section{University of California Hopland Field Station Research and Extension Center}

Over a period of about five years, beginning in the late 1990s, the University of California implemented a program to upgrade the road system at Hopland Field Station Research and Extension Center, located in Mendocino County. The work was largely funded by grants from the Department of Fish and Game (1999 SB 271 funds), Fisheries Restoration Grant Program. After an inventory and assessment of roads throughout the property, over 200 stream crossings and sections of road were prioritized for remedial treatment (fig. 36). Proposed treatments included replacement of culverts, installation of rolling dips and ditch relief culverts, and other measures intended to improve drainage, reduce sediment production, and generally reduce maintenance problems.

The entire program was implemented successfully by 2004. Although some newly installed culverts and fills experienced significant erosion during the first winter after construction, most post-project adjustments have diminished over time. Nearly all treatments have performed well, with a few fill failures at the outlets of rolling dips during spring 2006 (with very high precipitation). Maintenance needs and costs have declined dramatically. Personnel at the Field Station Center are especially satisfied with the superior performance of rolling dips as an alternative to cross drains for both reducing maintenance requirements and adequately draining road surfaces.

\section{Pinchard Creek Project}

The U.S. Forest Service partnered with Sierra Pacific Industries and Plumas County to upgrade a section of national forest road with serious erosion problems. The road's native surface was very erosive and lacked drainage structures. The surface was heavily rutted with rills over 2 inches deep and over 20 feet long (fig. 37). Road cut banks were unstable and eroding with more than 5 cubic yards of material moved, 40 percent of which was delivered to the stream channel. Roadside ditches were overloaded and degrading. One stream-crossing culvert entrance was more than 30 percent blocked with sediment and debris.

The project involved out-sloping the road surface, covering it with crushed rock, and installing drainage dips (fig. 38). Two years after the completion of the project, no surface ruts or road bank erosion has occurred, roadside drainage ditches are stable with little or no sediment delivery to the stream, and culvert entrances remain clear (fig. 39). The cost of the project was $\$ 221,603$, with 35 percent from National Forest road maintenance funds, 9 percent from Sierra Pacific Industries, and 56 percent from the Plumas County Resource Advisory Committee. 


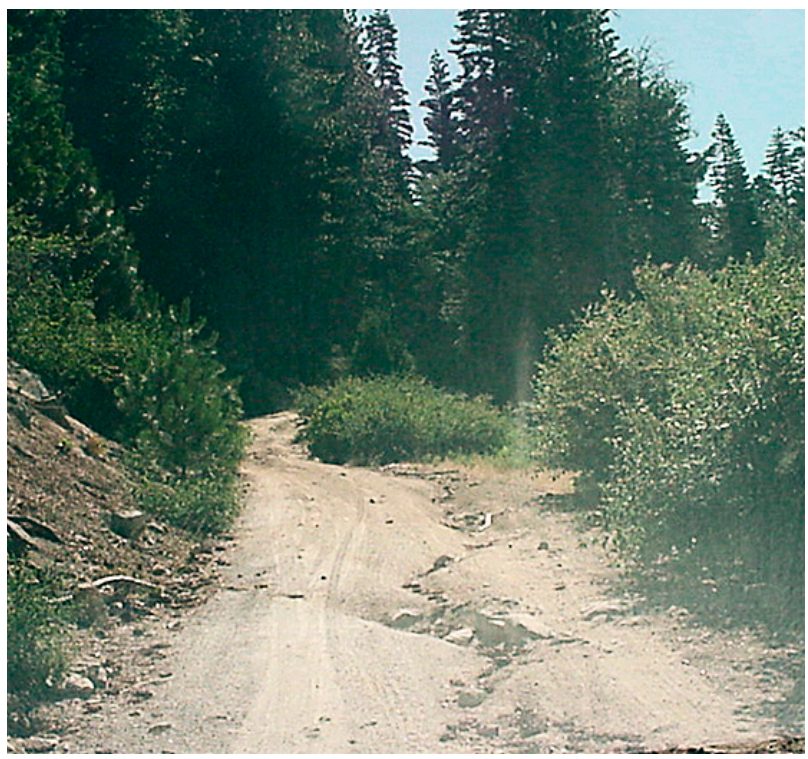

Figure 37. Pinchard Creek road with rilling along the road surface before the project, 2002. Photo: Joe Hoffman, Plumas National Forest.

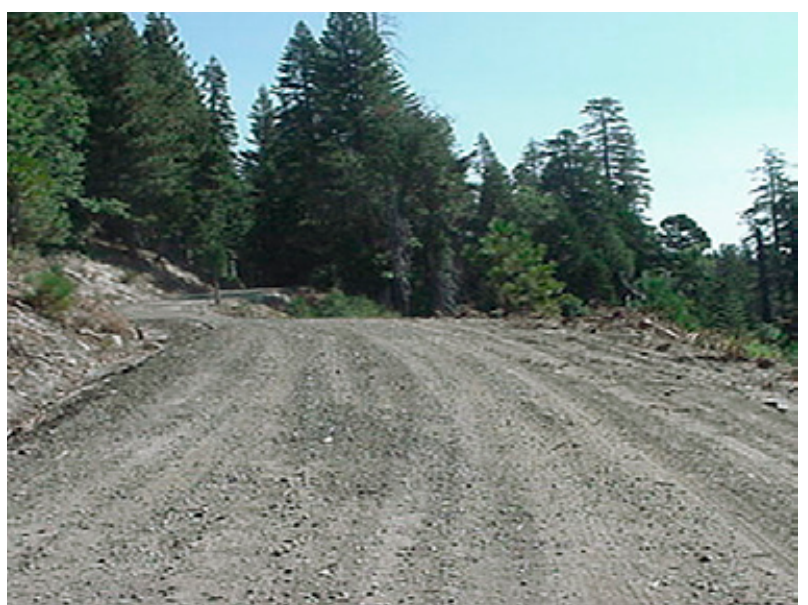

Figure 38. Pinchard Creek road immediately after project construction, 2002. Photo: Joe Hoffman, Plumas National Forest.

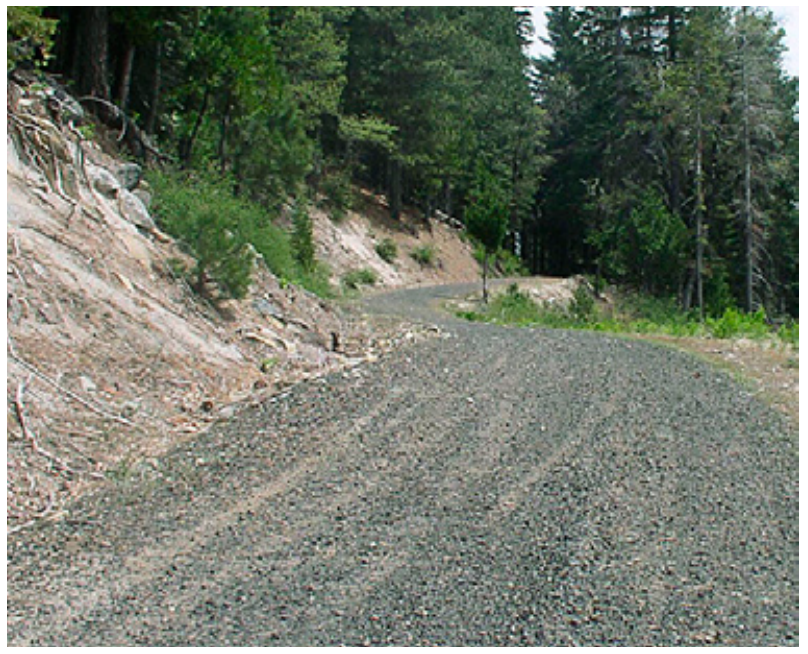

Figure 39. Pinchard Creek road two years after project construction, 2004. Note that the road surface remains in good shape without additional maintenance. Photo: Joe Hoffman, Plumas National Forest.

\section{BEST MANAGEMENT PRACTICES DURING CONSTRUCTION}

Construction of a new road necessarily involves a great deal of earth moving and soil disturbance. It is important that construction be managed wisely to avoid environmental impacts and damage to your property. One important thing a landowner can do is visit the site regularly during construction to ensure that the job is being done correctly. Sometimes plans made before construction are no longer feasible due to site constraints, and new decisions must be made. You need to be accessible to your contractor to help make these decisions when the situation arises.

Some general principles for best practices during construction are listed below:

- Minimize grading and soil disturbance.

- Develop an erosion control plan that includes measures on cut-and-fill slopes, drainage outlets, and disturbed areas (fig. 40).

- Avoid construction and soil disturbance in the winter.

- If construction does occur in the rainy season, ensure that the site has been storm proofed with erosion control measures when rains are forecast.

- Avoid incorporating logs or brush in the fill slope.

- Haul away excess sediment generated rather than side cast it onto the slope.

- Locate any stockpiled sediment in areas where it can be protected from erosion and will not deliver sediment to streams.

- Do not service or fuel heavy equipment where spills could enter a watercourse.

\section{POST-PROJECT ADJUSTMENT}

No matter how well planned and executed a road project has been, winter rains and traffic will lead to some adjustment of the final as-built condition during the first winter after improvements are made. Assuming that the road is in otherwise stable terrain, the adjustments will usually be minor and easily corrected. Adjustments may include some erosion of cut-and-fill slopes or culvert inlets and outlets (fig. 41). Road inspections should be done frequently during the new road's first winter season to identify any emerging problems for remediation. Developing problems may be averted with timely action. Plan for follow-up maintenance and put aside funds to perform the maintenance. 


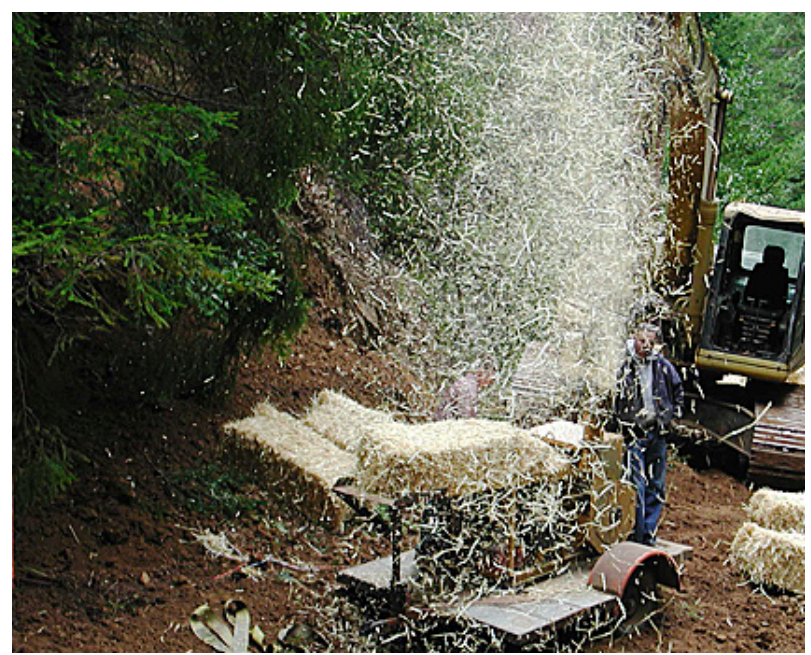

Figure 40. Using a portable blower to spread straw mulch on a disturbed road site. Photo: Julie Bawcom, California Geological Survey.

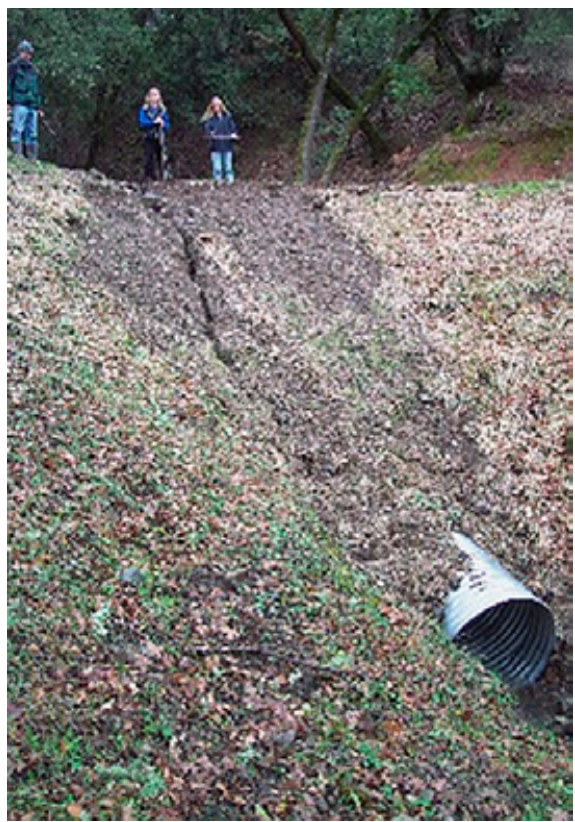

Figure 41. Fill surface erosion occurring after a road upgrading project. Photo: Bill Weaver, Pacific Watershed Associates.

\section{SOURCES}

For information on grants and cost sharing programs, check the online guides at

http://ceres.ca.gov/foreststeward/html/financial.html http://www.calwatershedfunds.org/ http://cwp.resources.ca.gov/grant_programs.html

For more information on road design and maintenance, consult the following resources:

Caferrata, P., T. Spittler, M. Wopat, G. Bundros, and S. Flanagan. 2004. Designing watercourse crossings for passage of 100-year flood flows, wood and sediment. California Forestry Report No. 1. Sacramento: California Department of Forestry and Fire Protection.

California Department of Forestry and Fire Protection (CAL FIRE). 2003. The changing California: Forest and range 2003 assessment. Sacramento: Fire and Resource Assessment Program (FRAP).

California Department of Fish and Game (CAL FIRE). 2004. Salmonid stream habitat restoration manual, part X: Upslope assessment and restoration practices. Sacramento: California Department of Fish and Game, Inland Fisheries Division.

Keller, G., and J. Sherar. 2003. Low volume roads engineering: Best management practices field guide. USDA Forest Service/USAID. National Transportation Library Web site, http://ntl.bts.gov/ lib/24000/24600/24650/Index_BMP_Field_Guide. htm

Kramer, B. 2001. Forest road contracting, construction, and maintenance for small woodland owners. Research Contribution No. 35, Corvallis: Oregon State University, Forest Research Laboratory.

USDA Forest Service. Riparian roads video short course. Oregon State University Forestry Sciences Laboratory Web site, http://www.fsl.orst.edu/geowater/RRR/.

Weaver, W. E., and D. K. Hagans. 1994. The handbook for forest and ranch roads: A guide for planning, designing, constructing, reconstructing, maintaining and closing wildland roads. Ukiah, California: Pacific Watershed Associates for the Mendocino County Resource Conservation District.

Wiest, R. L. 1998. A landowner's guide to building forest access roads. Radnor, PA: U.S. Department of Agriculture, Forest Service. Northeastern Area, State and Private Forestry NA-TP-06-98. 


\section{Metric Equivalents}

\begin{tabular}{|l|l|}
\hline English unit & Metric equivalent \\
\hline 1 inch (in) & 2.54 centimeters $\mathrm{cm})$ \\
\hline 1 foot (ft) & 0.3048 meters $(\mathrm{m})$ \\
1 mile (mi) & 1.609 kilometers $(\mathrm{km})$ \\
\hline 1 acre & 0.4047 hectares (ha) \\
\hline
\end{tabular}

\section{FOR FURTHER INFORMATION}

To order or obtain printed ANR publications and other products, visit the ANR Communication Services online catalog at http://anrcatalog.ucdavis.edu. You can also place orders by mail, phone, or FAX, or request a printed catalog of our products from

University of California

Agriculture and Natural Resources

Communication Services

6701 San Pablo Avenue, 2nd Floor

Oakland, California 94608-1239

Telephone: (800) 994-8849 or (510) 642-2431

FAX: (510) 643-5470

E-mail inquiries: danrcs@ucdavis.edu

An electronic version of this publication is available on the ANR Communication Services Web site at http://anrcatalog.ucdavis.edu.

Publication 8262

ISBN-13: 978-1-60107-483-6

(C) 2007 by The Regents of the University of California, Division of Agriculture and Natural Resources. All rights reserved.

To simplify information, trade names of products have been used. No endorsement of named or illustrated products is intended, nor is criticism implied of similar products that are not mentioned or illustrated.

The University of California prohibits discrimination or harassment of any person on the basis of race, color, national origin, religion, sex, gender identity, pregnancy (including childbirth, and medical conditions related to pregnancy or childbirth), physical or mental disability, medical condition (cancer-related or genetic characteristics), ancestry, marital status, age, sexual orientation, citizenship, or status as a covered veteran (covered veterans are special disabled veterans, recently separated veterans, Vietnam era veterans, or any other veterans who served on active duty during a war or in a campaign or expedition for which a campaign badge has been authorized) in any of its programs or activities. University policy is intended to be consistent with the provisions of applicable State and Federal laws.

Inquiries regarding the University's nondiscrimination policies may be directed to the Affirmative Action/Staff Personnel Services Director, University of California, Agriculture and Natural Resources, 1111 Franklin Street, 6th Floor, Oakland, CA 94607-5201, (510) 987-0096. For a free catalog of other publications, call (800) 994-8849. For help downloading this publication, call (530) 297-4445.

This publication has been anonymously peer reviewed for technical accuracy by University of California scientists and other qualified professionals. This review process was managed by the ANR Associate Editor for Natural Resources.

pr-8/07-LR/CM 